Portland State University

PDXScholar

\title{
The role of episcopal theology and administration in the implementation of the settlement of religion, 1559-c. 1575
}

Caroline J. Litzenberger

Portland State University

Follow this and additional works at: https://pdxscholar.library.pdx.edu/open_access_etds

Part of the European History Commons, and the History of Religion Commons Let us know how access to this document benefits you.

\section{Recommended Citation}

Litzenberger, Caroline J., "The role of episcopal theology and administration in the implementation of the settlement of religion, 1559-c. 1575" (1989). Dissertations and Theses. Paper 3983.

https://doi.org/10.15760/etd.5864

This Thesis is brought to you for free and open access. It has been accepted for inclusion in Dissertations and Theses by an authorized administrator of PDXScholar. Please contact us if we can make this document more accessible: pdxscholar@pdx.edu. 
AN ABSTRACT OF THE THESIS OF Caroline J. Litzenberger for the Master of Arts in History presented May 8, 1989.

Title: The Role of Episcopal Theology and Administration in the Implementation of the Settlement of Religion, 1559 - c.1575.

APPROVED BY MEMBERS OF THE THESIS COMMITTEE:
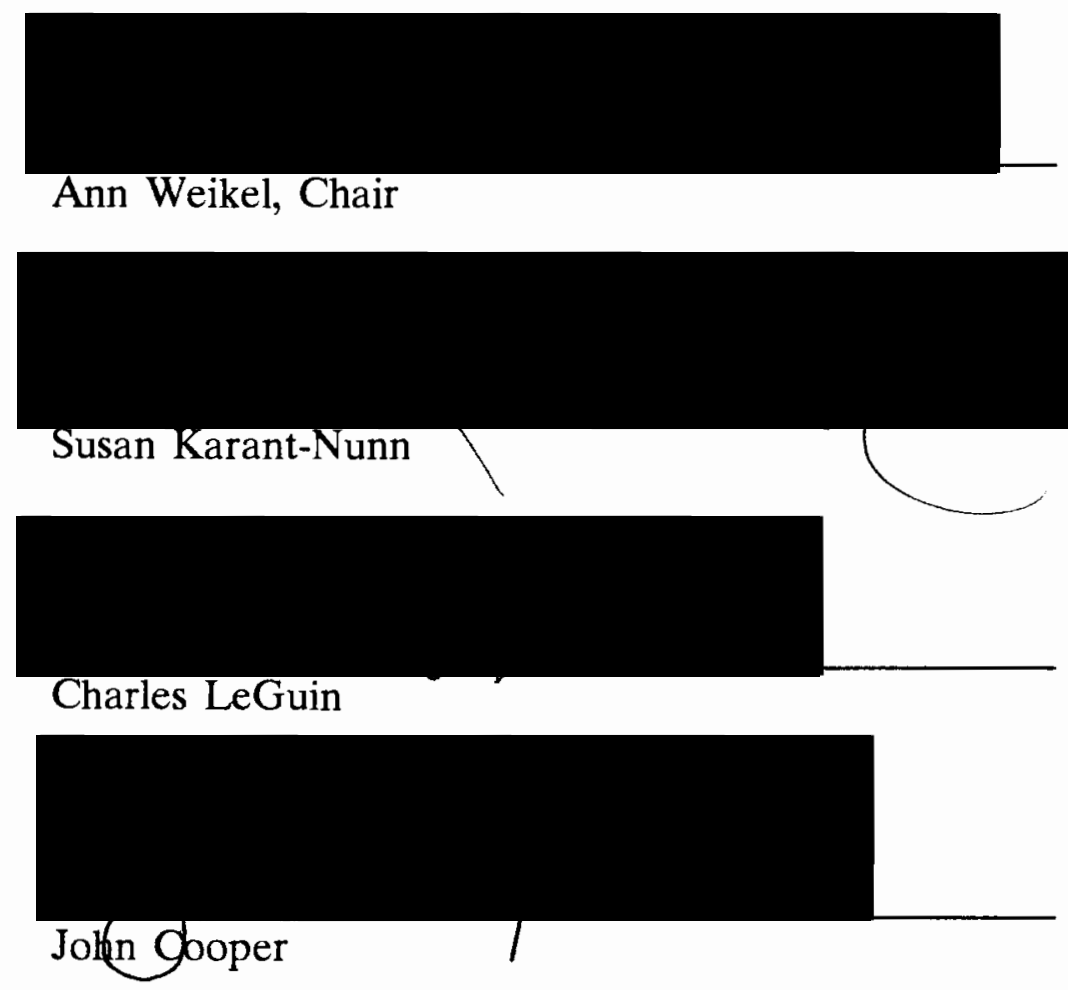

The term, Elizabethan Settlement, when applied solely to the adoption of the Prayer Book in 1559 or the Thirty-nine Articles in 1563, is misleading. The 
final form of the Settlement was the result of a creative struggle which involved Elizabeth and her advisors, together with the bishops and the local populace. The bishops introduced the Settlement in their dioceses and began a process of change which involved the laity and the local clergy. Through the ensuing implementation process the ultimate form of religion in England was defined.

Elizabeth seems to have had a clear vision of the form of Protestantism she wanted to restore to England, although there has been much debate about her personal theology. As Norman Jones says in Faith by Statute, for her the key was her authority as embodied in the royal supremacy. All else would follow. The secondary priorities were liturgy and theology, but primarily liturgy. The bishops' role in implementing her religious policy is illustrated by the theology and actions of three early Elizabethan bishops: Richard Cheyney of Gloucester, John Parkhurst of Norwich, and Richard Cox of Ely. Through their participation in the convocations, and, especially, through their individual episcopal administrations they helped define and implement the Settlement.

Cheyney and Parkhurst formed the "theological book-ends" for the early Elizabethan episcopacy. Parkhurst arguably was the most Protestant-the most radical. Cheyney was the most conservative - the closest to Catholicism. Cox was one of the many moderates. He was also one of the few skilled administrators. Elizabeth's bishops were often selected for their preaching ability, rather than for their administrative skills. Cheyney and Parkhurst, who more nearly represented the norm, lacked any significant administrative ability. 
By examining the theology and administration of these three men, it is possible to gain some understanding of the implementation of the Settlement of Religion and the durability of its final design. During the first half of Elizabeth's reign even the most theologically extreme bishops were fairly moderate. They may have preferred a more Protestant or a more Catholic form of religion, but they were willing to accede to the queen's authority and define a moderate form, even one which included some ambiguities. Thus they helped create a church which was theologically broad enough to allow for some private differences within the definition of outward conformity, provided by the liturgy. It was theologically broad enough to withstand the tests of successive generations of reformers and restorers, and to survive to the present in a form remarkably similar to that which was adopted by the Convocation of 1563 . 


\section{THE ROLE OF EPISCOPAL THEOLOGY AND ADMINISTRATION}

IN THE IMPLEMENTATION OF THE SETTLEMENT OF RELIGION,

$$
1559-\mathrm{c} .1575
$$

by

CAROLINE J. LITZENBERGER

A thesis submitted in partial fulfillment of the requirements for the degree of

MASTER OF ARTS

in

HISTORY

Portland State University

1989 
TO THE OFFICE OF GRADUATE STUDIES:

The members of the Committee approve the thesis of Caroline J.

Litzenberger presented May 8, 1989.

Ann Weikel, Chair

Susan Karant-Nunn

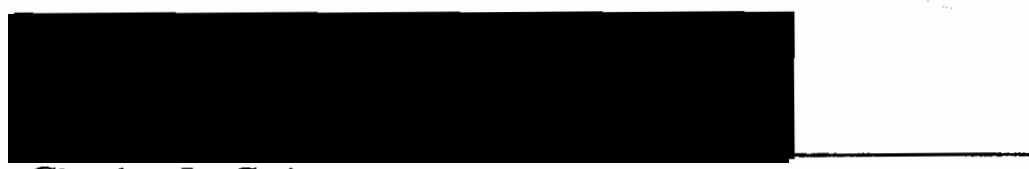

Charles LeGuin

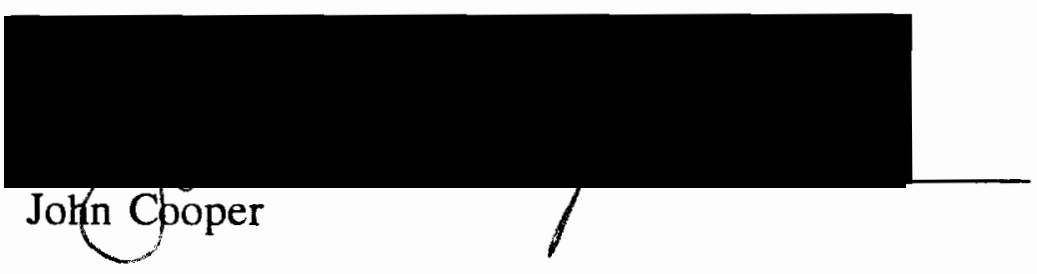

APPROVED:

Bernard V. Burke, Head, Department of History

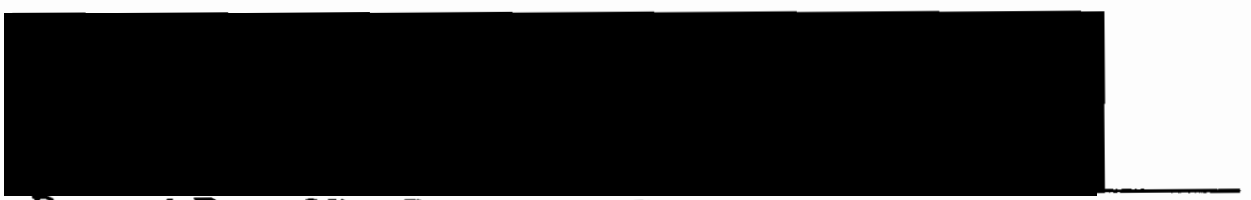

Bernard Ross, Vice Provost for Graduate Studies 


\section{ACKNOWLEDGEMENTS}

I want to take this opportunity to thank the many people who have encouraged, supported and guided me in my pursuit of a Masters Degree in history. I have found some outstanding teachers at Portland State University. First and foremost I want to express my appreciation and gratitude to my advisor, Ann Weikel. She has generously loaned me microfilm of manuscripts to aid me in my thesis research, and has guided and encouraged me throughout my two years as a graduate student in history. Her knowledge of English History and her teaching ability are impressive, and her generosity has extended beyond research materials to include expertise, advice, and support as well. Her presence on the faculty convinced me to enroll in Portland State and make English History my primary field, and I am very glad I did. I also want to express my gratitude to Susan Karant-Nunn for her sensitivity, support, and guidance. Her scholarship has been an inspiration to me.

Special thanks are also in order for significant contributions to this thesis by others. I would like to thank Gary Davis for his translation from Latin of selected passages from Cardwell's Synodalia. Thank you also to Kate Loggan, the Upper School Librarian at Oregon Episcopal School, for her assistance with interlibrary loans. I owe a special vote of thanks to Karen Adams, late of Portland State but now of Clare Hall College, Cambridge for obtaining portions 
of Bishop Richard Cox's Letter Book from the library of Gonville and Caius College, Cambridge. Thanks are also in order to the staffs of the libraries of Portland State University, the University of Washington, Reed College, the Graduate Theological Union in Berkeley, California, the Episcopal Divinity School in Cambridge, Massachusetts, and Gonville and Cauis College, Cambridge, England.

My return to graduate school has sometimes been a rather daunting experience. I want to take this opportunity to thank some special people who have helped me along the way with love, support and encouragement: Roy and Sharon Coulter, Susan and Sherman Hesslegrave, Mariann Koop, Allan and Stephanie Oliver, David and Jeanne Pace, John and Alice Scannell, Ann and George Smith, and Ann Wetherall. I also want to thank a number of my fellow students for their friendship, including Judy Armstrong, Lynn Botelho, Carol DeWitte, Susan Dubay, Firyal Isa, Sylvia Kaplan, Dianne Lynch, Susan Mosedale, Jerry Packard, Dorothy Rackley, Ken Schafer, and Niobeh Tsaba. But my deepest gratitude goes to four very special people: to Frank Wall, who has patiently supported me through the long hours of research and writing; to Patty and Dale Walhood, who have been a constant source of strength and reassurance; and to my son, Brian, who through his particular gifts helped me decide to travel this path, and who has been a constant source of encouragement and affirmation. 
TABLE OF CONTENTS

PAGE

ACKNOWLEDGEMENTS $\ldots \ldots \ldots \ldots \ldots \ldots \ldots \ldots \ldots$ iii

CHAPTER

I INTRODUCTION $\ldots \ldots \ldots \ldots \ldots \ldots \ldots \ldots \ldots \ldots$

II OVERVIEW OF THE ENGLISH REFORMATION . . . . 10

III THE CONVOCATION OF $1563 \ldots \ldots \ldots \ldots \ldots \ldots, 32$

IV RICHARD CHEYNEY $\ldots \ldots \ldots \ldots \ldots \ldots \ldots, 46$

V JOHN PARKHURST $\ldots \ldots \ldots \ldots \ldots \ldots \ldots \ldots 64$

VI RICHARD COX .................. 79

VII CONCLUSIONS $\ldots \ldots \ldots \ldots \ldots \ldots \ldots \ldots \ldots \ldots$

ABBREVIATIONS $\ldots \ldots \ldots \ldots \ldots \ldots \ldots \ldots \ldots \ldots \ldots \ldots \ldots \ldots$

REFERENCES $\ldots \ldots \ldots \ldots \ldots \ldots \ldots \ldots \ldots \ldots \ldots \ldots \ldots \ldots \ldots \ldots$ APPENDICES

A BISHOPS OF THE CHURCH OF ENGLAND IN $1563 \ldots 122$

B ACTIVITIES OF ELIZABETHAN BISHOPS DURING MARY'S REIGN . . . . . . . . . . . . . . . 124 


\section{CHAPTER I}

\section{INTRODUCTION}

The term, Elizabethan Settlement, when applied solely to the adoption of the Prayer Book in 1559 or the Thirty-nine Articles in 1563, is misleading. Neither was the Settlement totally Elizabeth's nor was the form of religion completely settled. The final form of the Settlement of Religion came later and was the result of a creative struggle. Elizabeth and her advisors, together with the bishops and the local populace, both clerical and lay, shaped the final form of the English Church between 1563 and approximately 1575. Much has been written about Elizabeth's role in this process. ${ }^{1}$ Less research has been done on the roles of the bishops and the local populace. In the future I hope to research aspects of popular religion, perhaps as it relates to the Elizabethan Settlement. However, in this thesis, because of the availability of sources, I have chosen to focus on the role of the bishops.

The process of implementing the Settlement involved the process of introducing change into the populace through the bishops and their individual diocesan administrations. The bishops in this instance were agents of change.

1. William Haugaard, Norman L. Jones and J. E. Neale have all written on Elizabeth's involvement in the Settlement of Religion. 
However, the early Elizabethan bishops espoused a range of theological beliefs which was broader than that embodied in the Settlement as originally proposed. First, they, themselves, had to accept the Settlement. Then they could begin to introduce and enforce it among the laity and local clergy. However, the process was influenced by a complex set of factors other than theology. These factors included the personalities and administrative abilities of the individual bishops, and the theology and personalities of the individuals within the local parishes. In this thesis I focus primarily on the theology and administrative abilities of the bishops. The other factors were peripheral to the scope of my research.

The religion of the people-the laity and local clergy-ranged from papist (Catholic) to ardent reformer, including Calvinist and even Anabaptist. Calvinism was strong in Norwich, Bristol and Coventry by $1559 .^{2}$ The diocese of Ely had Calvinists in St. John's College, Cambridge. ${ }^{3}$ Recusant Catholics could be found in every diocese. ${ }^{4}$

When the bishops began to introduce the Settlement, many of the people resisted the resulting changes, and most of the bishops lacked the administrative

2. A. G. Dickens, "The Early Expansion of Protestantism in England, 15201558," Archive for Reformation Research 78 (January, 1987): 197.

3. John Strype, Annals of the Reformation and Establishment of Religion, and Other Various Occurrences in the Church of England, during Queen Elizabeth's Happy Reign, Vol. 1, Part 1 (Oxford: Clarendon Press, 1824), 157-59.

4. Christopher Haigh, "The Continuity of Catholicism in the English Reformation," in The English Reformation Revised, ed. Christopher Haigh (Cambridge: Cambridge University Press, 1987), 178. 
skills to enforce them as introduced. As a general rule, Elizabeth and her advisors seem to have selected the bishops for their relatively moderate theological beliefs and their ability to preach, rather than for their administrative skills. $^{5}$ Thus, the process of implementing the Settlement of Religion became a process of redefining it as well. Through the creative tensions engendered by combining these various factors, a Settlement was achieved which was more inclusive and, therefore, more durable than the original version. The bishops played a key role in this accomplishment. Without their dedicated participation the Settlement would have been narrower and would have appealed to fewer people.

In examining the early Elizabethan bishops, it is possible to describe three theological groupings. The conservatives had served the church in some capacity under Mary and supported every effort to return the church to Henrician Catholicism. The moderate reformers tended to support Elizabeth's religious policies even when those policies changed. The more zealous reformers wanted a simpler liturgy and a theology which resembled Calvinism.

The most conservative of the bishops were probably Thomas Davies of St. Asaph's, Richard Cheyney of Gloucester, and William Downham of Chester.

5. Ralph A. Houlbrooke, "The Protestant Episcopate 1547 - 1603: The Pastoral Contribution," in Church and Society in England: Henry VIII to James I, ed. Felicity Heal and Rosemary O’Day (London: Macmillan Press, 1977), 82-83; Patrick Collinson, "Episcopacy and Reform in England in the Later Sixteenth Century," in Godly People: Essays on English Protestantism and Puritanism (London: Hambledon Press, 1983), 171-72. 
The most zealous reformer was probably John Parkhurst of Norwich. Others who might be grouped with him would include Edwin Sandys of Worcester and Edmund Grindal of London, although they seem to have adopted less radical positions than Parkhurst. There were a number of moderate reformers: Nicholas Bullingham of Lincoln, Richard Cox of Ely, Edmund Guest of Rochester, John Jewel of Salisbury, and John Scory of Hereford. Matthew Parker, the archbishop and presiding officer of the meetings of the Convocation in 1563 and 1571, was also a moderate. These three bishops also represent the range of administrative abilites found among the early Elizabethan bishops. Cox was an energetic and effective administrator. Cheyney and Parkhurst were weak and inept.

This thesis focuses on one representative bishop from each of these three groups: the conservative, Richard Cheyney of Gloucester, the zealous reformer, John Parkhurst of Norwich, and Richard Cox of Ely, the moderate.

Richard Cheyney was one of the few early Elizabethan bishops who had retained his preferments during the reign of Mary. He was archdeacon of Hereford when Mary became queen and held that preferment until 1557 when he became a canon of Gloucester Cathedral. In 1553 he was one of five opponents of transubstantiation to participate in a disputation on that theory of the Eucharist. However, his theory of the Eucharist appears to have been 
conservative enough to keep Mary's trust. ${ }^{6}$ Haugaard describes Cheyney as the most conservative of Elizabeth's initial episcopal appointments. ${ }^{7}$

Parkhurst may have been the most radical reformer among Elizabeth's first group of bishops. He wrote a letter to Bullinger in April 1562, just before the Convocation of 1563 , in which he expressed his hope that the coming convocation would improve the Church of England. He wrote:

There are many good and zealous men; there are many too cold, and not a few lukewarm. ... B But to be plain with you, I fear many evils are hanging over our heads. For almost all are covetous, all love gifts. There is no truth, no liberality, no knowledge of God. . . . But God grant that we may repent from our inmost soul! ${ }^{8}$

6. Transubstantiation was the papist (Catholic) explanation of the Real Presence of the body and blood of Christ in the Mass. A more complete discussion of this topic is included below, in Chapter II. The disputation was ordered by Mary and was held at the beginning of the Convocation of 1553. Edward Cardwell, ed., Synodalia. A Collection of Articles of Religion, Canons, and Proceedings of Convocations in the Province of Canterbury, From the Year 1547 to the Year 1717, Vol. 2 (1842; reprint, Farnbourough, Hants.: Gregg International Publishers, Ltd., 1968), 425-26.

7. William Haugaard, Elizabeth and the English Reformation: The Struggle for a Stable Settlement of Religion (Cambridge: Cambridge University Press, 1968), 23-24, 204.

8. Parkhurst to Bullinger, from Ludham, 28 April 1562, in The Zurich Letters, Comprising the Correspondence of Several English Bishops and others with some of the Helvetian Reformers, during ... the Reign of Queen Elizabeth, Vol. 1, ed. Hastings Robinson (Cambridge: Cambridge University Press, 1842), 108. 
He had spent the years of Mary's reign in Zurich as a guest of Rodolph Gualter and had come to appreciate the simple form of liturgy practiced there. ${ }^{9}$

Richard Cox was one of the leading moderates, and the Elizabethan bishop with the strongest ties to the Edwardian Reformation. He, along with all the other moderate leaders except Guest, lived in exile during Mary's reign. In general, the exiles tended to fall into two groups: those who supported the continued use of the Book of Common Prayer of 1552 (or a similar liturgy); and those who opposed the Prayer Book and preferred an English-language liturgy based on a Calvinist model. No one from the anti-Prayer Book group was appointed to a bishopric at the beginning of Elizabeth's reign. The Prayer Book group had resided primarily in Strassburg, Zurich, and Frankfurt. ${ }^{10}$ Richard Cox had lived in Strassburg and then in Zurich during his exile, and his appearance and actions in Frankfurt made him the leader of the Prayer Book group among the exiles. ${ }^{11}$

Cox had matured as a priest during the reigns of Henry VIII and Edward VI. He was on the commission which drafted "The Necessary Doctrine and

9. Parkhurst to Gualter, from Ludham, 6 Feb 1574, in The Letter Book of John Parkhurst, Bishop of Norwich, compiled during the years 1571-5, ed. R.A. Houlbrooke (Norwich: Norfolk Record Society, 1974/5), 81.

10. However, the congregation at Emden may have held similar views. Haugaard, Elizabeth and the English Reformation, 26-31.

11. Christina H. Garrett, The Marian Exiles: A Study in the Origins of Elizabethan Puritanism (1938; reprint, Cambridge: Cambridge University Press, 1966), 99, 134-36. 
Erudition of a Christian Man" in 1540, and the same year became archdeacon of Ely. In 1547 he became dean of Christ Church Cathedral in Oxford, and in 1548 he was on the Windsor Commission which may have been involved in the drafting of the new liturgies introduced during the reign of Edward VI. ${ }^{12}$

My thesis sketches the theology and related life experiences of each of the selected bishops and describes each man's administrative abilities. Since these three bishops are representive of the early Elizabethan episcopacy, it is possible to gain some insight into the bishops' role in implementing the Settlement by focusing on them.

The sources presented certain problems for my research. While I relied as much as possible on the bishops' own writings, I also considered the opinions and analyses of other historians. The works of John Strype presented the greatest challenge because of his treatment of primary sources. Authorities such as Haugaard and Thompson have indicated that Strype's treatment of sources is unreliable. He often identified documents only by the general collection from which they came, and there are indications that the transcriptions of the documents are unreliable. Strype included longer documents in appendices to the various volumes, usually presenting these as verbatim transcriptions. Yet, occasionally he omitted passages he judged to be extraneous or uninteresting. He often paraphrased, or at least changed into third-person accounts, those

12. Garrett, Exiles, 134. 
documents which he reproduced in the body of the text. A more serious weakness in Strype's versions of these sources is the inaccuracy of his transcriptions. According to Thompson, the length of time that intervened between taking the notes and publishing the results affected Strype's accuracy. Therefore, he reproduced sources more accurately when they came from collections he possessed, such as John Foxe's manuscripts or a large collection of Lord Burghley's papers. ${ }^{13}$ In researching the actions of the Convocation of 1563 I was particularly indebted to William Haugaard for his very thorough analysis of the pertinent documents, comparing the Petyt manuscripts from the Inner Temple with Strype's version. ${ }^{14}$

I did have access to some primary sources other than those edited by Strype. I was able to read selected manuscripts from the British Library Lansdowne Collection on microfilm, as well as a photocopy of selections from Bishop Cox's Letter Book, which is in manuscript form. I also used printed primary sources including collections of statutes, proclamations, and letters, and reprinted editions of the first three Prayer Books.

The nature of the available sources dictated a different treatment of each bishop's theology and administrative abilities. The information concerning

13. W. D. J. Cargill Thompson, "John Strype as a Source for the Study of Sixteenth Century English Church History," in The Materials, Sources and Methods of Ecclesiastical History, ed. Derek Baker (Oxford: Basil Blackwell, 1975), 241-42.

14. Haugaard, Elizabeth and the English Reformation, 342-56. 
Cheyney is quite meager. Most of it is theological. There is very little information concerning his actions or episcopal administration. Therefore, I present and analyze his theology and touch on his episcopal administration, providing only a brief glimpse of the other aspects of his life. The information available on Parkhurst, on the other hand, focuses on either his actions and the administration of his diocese, or on his positions on issues, which are grounded in theology, but are not, of themselves, primarily theological. Therefore, I describe his theology by relating and analyzing his actions and his positions on the issues of the day. The information on Cox is more extensive. It addresses both his theology and his actions over most of the course of his very long life, so it is possible to discuss his life, theology, and administration directly from the available documentation.

Before discussing the three bishops, I include information on the English Reformation and the Convocation of 1563 as background. 


\section{CHAPTER II}

\section{OVERVIEW OF THE ENGLISH REFORMATION}

The first phase of the Reformation in England was precipitated primarily by Henry's concern for the succession of the crown. After extended negotiations, ${ }^{15}$ he gave up hope of receiving a papal annulment of his marriage to Catherine of Aragon. Thomas Cranmer, his new archbishop of Canterbury, granted him a divorce on 23 May 1533, and five days later declared his January 1533 marriage to Anne Boleyn lawful. ${ }^{16}$ These acts combined with the subsequent passage of a series of statutes by Parliament severed England's relationship with the papacy. In 1534 Parliament passed the Act of Supremacy and the first Act of Succession, which declared Henry's right to supremacy over the church in England, validated his marriage to Anne Boleyn, and required allegiance to her and to their children. These acts were followed in 1536 by the initiation of the dissolution of the monasteries and the second Act of Succession following his marriage to Jane Seymour. ${ }^{17}$

15. A. G. Dickens, The English Reformation (New York: Schocken Books, 1964), 106-108.

16. Geoffery R. Elton, Reform and Reformation: England, 1509-1559 (Cambridge, Massachussetts: Harvard University Press, 1977), 175, 178.

17. English Historical Documents, Vol. 5, 1484-1558, ed. C. H. Williams (New York: Oxford University Press, 1967), 437-56. 
Throughout Henry's reign the Reformation in England was more political than theological. However, some minor theological changes resulted in a very limited introduction of the vernacular into the liturgy. The Injunctions of 1538 ordered that every church in England obtain a copy of the Bible (in English). In 1544 a new Litany (in English) was issued in response to Henry's order that there be processions throughout the province of Canterbury to pray for him in his war with France. During this time there was also a decrease in the number of saints recognized by the Church of England. ${ }^{18}$

The Henrician Reformation occurred against a backdrop of the Protestant Reformation on the continent, which primarily grew out of the spread of Renaissance humanism and the writings and preaching of Martin Luther. Scholars and theologians in England were influenced by both Luther and humanism. It was a time of great intellectual ferment. Those who were so influenced included Thomas Cromwell, the architect of Henry's religious policy during the 1530s, and Thomas Cranmer, the archbishop of Canterbury. Others who were influenced included Richard Cox, John Parkhurst, and Richard Cheyney, and ultimately, Edward VI and Elizabeth I.

The Protestant sympathies of Edward and Elizabeth contributed directly to the progress of the English Reformation. Edward's regents and, later,

18. Horton Davies, Worship and Theology in England: From Cranmer to Hooker, 1534-1603 (Princeton: Princeton University Press, 1970), 12; G. J. Cuming, A History of Anglican Liturgy, 2nd ed. (London: Macmillan, 1982), 35. 
Elizabeth continued the political reforms begun by their father, Henry VIII. However, they also added significant theological and liturgical aspects to the Reformation. The Protestant Reformation in England really began with the reign of Edward VI.

Following Edward's accession to the throne, the English Church began to move toward a more Protestant theology, primarily through changes in the liturgy. In 1547 Parliament passed the "Act Against Revilers and for Receiving in Both Kinds." A few months later the Duke of Somerset, who was the Protector, and Cranmer, the archbishop of Canterbury, introduced the vernacular into the Mass by requiring the use of the Order of Communion of $1548 .^{19}$ These changes were followed in 1549 by the "First Act of Uniformity," which required the use of the first Book of Common Prayer. In this book the various worship services were completely in English, although the words had been carefully chosen and the liturgy structured to allow for a broad range of beliefs. In the fall of 1552 Parliament passed the second "Act of Uniformity," which required the use of the second Book of Common Prayer. At this point many of

19. When both the bread and the wine were administered to the laity, the laity was described as "receiving in both kinds." The Order of Communion was needed because the Mass did not include words for administering the wine to the laity. However, Sommmerset and Cranmer went much further than the act required by using the vernacular and by adding a general confession and absolution as well. "Act Against Revilers and for Receiving in Both Kinds," in Documents Illustrative of English Church History, ed. Henry Gee and William J. Hardy (New York: Macmillan and Co., 1896), 322-28; Francis Proctor and Walter Frere, A New History of the Book of Common Prayer (London: Macmillan and Co., 1914), 38. 
the ambiguities contained in the first book had been removed to reflect a more clearly Protestant theology.20

On 6 July 1553, approximately eight months after the introduction of the second Prayer Book, Edward VI died. ${ }^{21}$ He was succeeded by Mary, who immediately instituted a policy to restore Catholicism to England. A number of English Protestants were martyred, including Thomas Cranmer. Many others escaped to the continent, where they lived in exile for the duration of Mary's reign. Still others remained in England and escaped the burnings either by living anonymously in the country or by adopting some measure of accommodation to the religious policies of the time. ${ }^{22}$

Mary died on 17 November 1558 and the attempted Catholic Restoration died with her. ${ }^{23}$ She and her advisors, most notably Cardinal Reginald Pole, ${ }^{24}$ had made several strategic errors. First, they had created martyrs to

20. The First and Second Prayer Books of Edward VI, Everyman's Library (1910; reprint, London: J. M. Dent, 1960), passim.

21. C. H. Smyth, Cranmer and the Reformation under Edward VI (Cambridge: Cambridge University Press, 1926), 289.

22. See Appendix B for a list of the bishops of 1563 and their activities during Mary's reign.

23. Robert Titler, The Reign of Mary I (New York: Longman, 1983), 80.

24. Reginald Pole was an Englishman who had lived in Italy since the 1520's, except for a brief return to England from 1529 to 1532 . His return to Padua in 1532 was prompted by his refusal to accept the break with Rome. He returned to England in November 1554 as the papal legate. Titler, Mary, 29. 
Protestantism by prosecuting some of the key leaders of the Edwardian

Reformation, as well as many other less prominent reformers. Second, they had chosen to restore Catholicism through authority and the church hierarchy, rather than relying on education and evangelism through preaching and the printed word. This approach seems to have been based on two assumptions: the laity would welcome a return to Catholicism; the English clergy were capable of implementing and enforcing the change. Both of these assumptions were seriously flawed. They grew out of Pole's unfamiliarity with England at this time. He thus determined to follow what Rex Pogson describes as a "legalistic approach," which would provide stability and prepare people to hear and accept "the right ideas."25 The strategy did not work. However, historians disagree as to whether it would have worked if Mary had lived longer.

Elizabeth's accession to the throne brought renewed hope to the Protestant reformers. Those who had been living in exile began to return home at once. ${ }^{26}$ Those who had been living in hiding in England reappeared. The clergy who had conformed under Mary either fought the move toward

25. Rex H. Pogson, "Reginald Pole and the Priorities of Government in Mary Tudor's Church," The Historical Journal, 18 (1975): 12-13; Pogson, "The Legacy of the Schism: Confusion, Continuity and Change in the Marian Clergy," in Mid-Tudor Polity c. 1540-1560, ed. Robert Titler and Jennifer Loach, (Totowa, New Jersey: Rowman and Littlefield, 1980), 117, 136.

26. Almost all the preachers before the queen and parliament during the first few months of Elizabeth's reign were returned exiles. Strype, Annals, Vol. 1, Part 1, 60. 
Protestantism and were deprived of their preferments, or attempted to explain their conformity in terms which would be acceptable to the Protestants. ${ }^{27}$

Elizabeth's religious policy, which has been labeled the Elizabethan Settlement, was the result of a combination of statutes and royal proclamations, most of which were enacted in 1559.

J. E. Neale and Norman Jones have both done extensive research on the events of 1559 that contributed to the Settlement of Religion. Jones's work is more recent, and he has taken issue with a number of Neale's assumptions and conclusions. However, both men describe the dearth of evidence concerning those events. Neale says,

It is a tribute to the enduring qualities of the settlement that in looking back it has seemed natural and inevitable: as though from the beginning there could have been no other policy than that of the middle way-the via media of tradition. But when and how this policy was shaped, or even what happened in Parliament, has been a matter of guesswork, based on the most meagre and baffling evidence. $^{28}$

27. Richard Cheyney was a case in point, although there is no record of him defending his actions until 1571. He had attended Mass during Mary's reign, however, there is no record of his ever having presided. In defense of his actions he cited the story of Namaan's attendance at a service of idol-worship to show that, according to Scripture, it was possible to be present at a worship service which is contrary to one's own beliefs without committing a sin. Strype, Annals, Vol. 1, Part $2,279$.

28. J. E. Neale, Elizabeth I and Her Parliaments, 1559-1581 (1958; reprint, New York: W. W. Norton and Co., 1966), 51. 
Jones points out that "no important new documents that would alter the story have been uncovered since the late nineteenth century." ${ }^{19}$ Explaining the reasons for Elizabeth's actions during the early months of her reign has been one of the challenges faced by historians. This is one of the points on which Jones and Neale disagree.

A thorough discussion of the events of the first few months of Elizabeth's reign is beyond the scope of this thesis. However, some discussion of Elizabeth's personal religious preferences may contribute to a better understanding of the results of those events, and of her relations with her bishops over the course of her reign.

Neale gives a clue of his understanding of Elizabeth's preferences and motivations when he describes the results of the settlement process.

The main structure of the Elizabethan religious settlement was now determined. In giving way to the Protestant divines Elizabeth had been wise. Thereby she obtained as conservative and comprehensive a Church as was possible. .. . The Queen did not forget her defeat. Her vigorous action in the Vestiarian controversy ... suggests more than statecraft: it suggests a passionate resolve to have the pound of flesh provided for in her bond. Doubtless she detested Puritanism the more for having wrested so much from her in this Parliament. ${ }^{30}$

According to Neale, Elizabeth was angered by the recalcitrance of the most zealous reformers, and some of her actions were prompted by a desire for

29. Norman L. Jones, Faith by Statute: Parliament and the Settlement of Religion 1559 (New Jersey: Humanities Press, 1982), 3.

30. Neale, Elizabeth I, 82-83. 
revenge. He believes she wanted to restore Henrician Catholicism to England. ${ }^{31}$

Jones sees Elizabeth clearly as a Protestant. Further, he says,

The royal supremacy was at the very centre of both her political and religious ideals. ... I It would seem that what so upset Elizabeth's episcopate was her broad application of the idea of adiaphora. She was as Protestant as Jewel, Grindal or Cox, but she was more tolerant than they towards popish (or Lutheran) behaviour.

He goes on to assert that Elizabeth did not reject either the Prayer Book of 1552 or the theology that Parkhurst and others had found in Switzerland. ${ }^{32}$

Jones' arguments concerning Elizabeth's theology are very convincing. Further, the evidence seems to confirm both her fundamental Protestantism and her designation of many aspects of liturgy, such as vestments and images, as indifferent to theological belief. However, while she may have been more tolerant of papist behavior than most of her bishops, she appears to have been less tolerant of Calvinist behavior. Perhaps her Protestantism was closer to Lutheranism than that of most of her bishops. Ultimately, her religion was only one of the factors which contributed to the final form of Christianity embodied in the Church of England. Her political skills and the theology and administrative skills of her bishops were more important factors in the final form of the Settlement.

The development of Elizabeth's religious settlement began shortly after

31. J. E. Neale, "The Elizabethan Acts of Supremacy and Uniformity," English Historical Review, 65 (July, 1950): 311.

32. Jones, Faith by Statute, 9. 
her accession. On December 28 she moved to keep control of religion by issuing a proclamation prohibiting unlicensed preaching and the use of any unauthorized liturgy. ${ }^{33}$ Parliament convened on 25 January 1559, and the process which would lead to the next official steps in the Settlement began. Following much debate and negotiation, and the drafting and printing of a proclamation which was never issued, ${ }^{34}$ Parliament finally approved both the Act of Supremacy and the Act of Uniformity on 29 April 1559.

The Act of Supremacy was clearly an act of restoration. After specifically naming and describing a series of Henrician statutes, it said that, "all and every branches, words, and sentences in the said several Acts and statutes contained ... shall be revived, and shall stand and be in full force and strength, to all intents, constructions and purposes." It also restored portions of a number of other Henrician and Edwardian statutes, repealed the Heresy Acts of Mary's reign, and revived the entire Edwardian "Act Against Revilers [of the Sacrament of the Altar] and for Receiving in Both Kinds," which had been the first statute

33. The use of the Lord's Prayer and Creed in English, and the Litany then in use in the queen's chapel, was specifically permitted. Selected Statutes and other Constitutional Documents Illustrative of the Reigns of Elizabeth and James I, 2nd ed., ed. G. W. Prothero (Oxford: Clarendon Press, 1898), 183-84.

34. The unissued proclamation was dated 22 March 1559, and would have directed the administration of communion in both kinds. It was apparently drafted with the expectation that parliament would be dissolved on March 24, before Easter. Communion in both kinds was the only liturgical change that had been authorized by parliament at that time. Tudor Royal Proclamations, Vol. 2, The Later Tudors, (1553-1587), ed. Paul L. Hughes and James F. Larkin (New Haven: Yale University Press, 1969), 109-10; Jones, Faith by Statute, 114. 
of Edward's reign, enacted in $1547 .^{35}$ Finally, it named Elizabeth the "supreme governor" of the church, articulated her rights and powers, and provided for the enforcement of the act. This was much more complex that the Henrician Act of Supremacy of $1534 .^{36}$

The other step in restoring Protestantism to England was accomplished by the Act of Uniformity of 1559 . This repealed Mary's act which had repealed the second Edwardian Act of Uniformity. Further, this act established penalties for non-conforming clergy and for speaking against the established form of worship. Also, it provided that everyone "having no lawful or reasonable excuse to be absent" was to attend church each Sunday, as well as every holy day, or pay a fine to the poor. Further, it established a slightly revised version of the Prayer Book of 1552 as the established liturgy. However, it also provided that

Such ornaments of the church, and of the ministers thereof, shall be retained and be in use, as was in the Church of England, by authority of Parliament, in the second year of the reign of King Edward VI, until other order shall be therein taken by the authority of the queen's majesty. ${ }^{37}$

35. "Act Against Revilers and for Receiving in Both Kinds," in Documents, ed. Gee and Hardy, 322-27.

36. "An Act Restoring to the Crown the Ancient Jurisdiction of the State Ecclesiastical and Spiritual, and abolishing all Foreign Power Repugnant to the Same," in Henry Gee, The Elizabethan Clergy and the Settlement of Religion, 1558-1564 (Oxford: Clarendon Press, 1898), 9-22; "The Act of Supremacy, 1534," in The Reformation in England to the Accession of Elizabeth I, ed. A. G. Dickens and Dorothy Carr (1967; reprint, London: Edward Arnold Ltd., 1971), 64-65.

37. "An Act for the Uniformity of Common Prayer and Service in the Church and Administration of the Sacraments," in Gee, The Elizabethan Clergy, 2229. 
This provision of the Act of Uniformity was to be the source of great controversy over the next several years. It created confusion for many because it referred to the ornaments of 1549 , whereas the established liturgy was basically that of 1552 .

A comparison of the two Prayer Books-1552 and 1559-shows that there were, in fact, few changes introduced in the latter. Several changes were made to the Litany, but the only change of significance was the deletion of the phrase, "from the tyranny of the Bysshop of Rome and al hys detestable enormities [deliver us]." ${ }^{138}$ Also, the "Black Rubric" was deleted from the Communion Service. This rubric, which had been added to the Prayer Book of 1552 at the last moment, explained that kneeling at Communion was intended to signify "the humble and gratefull acknowledgyng of the benefites of Chryst," not "any adoracion ... [or] anye reall and essencial presence ... of Christ's naturall fleshe and bloude."139

The most significant changes pertained to the provisions concerning ornaments and to the administration of the elements in the Eucharist. The Prayer Book of 1552 contained very explicit language which directed that "the minister at the tyme of the Comunion and all other tymes in his ministracion,

38. Prayer Books, 362.

39. Prayer Books, 393. 
shall use neither albe, vestment, nor cope."40 The Prayer Book of 1559 stipulates that

The minister at the time of the Communion, and at all other times in his ministration, shall use such ornaments in the church as were in use by authority of Parliament in the second year of the reign of King Edward the Sixth. ${ }^{41}$

The ornaments rubric in the Prayer Book of 1549 (the second year of Edward VI's reign) states that

At the tyme appoincted for the ministracion of the holy Communion, the Priest that shal execute the holy ministery, shall put upon hym the vesture appoincted for that ministracion, that is to saye: a white Albe plain, with a vestement [chausible] or Cope. And where there be many Priestes, or Decons, there so many ... shall haue upon them lykewise the vestures appointed for their ministery, that is to saye, Albes with tunacles. ${ }^{42}$

The words of administration incorporated in the Communion service of each of the first two Prayer Books had been carefully chosen to express the accepted range of beliefs concerning the Real Presence of Christ in the elements. In 1549 the references were to the body and blood of Christ, exclusively. In 1552 the references to the body and blood were omitted and the communicant was told to "Take and eate [or drinke] this, in remembraunce." The Prayer Book of 1559 combined the two, using the exact words from each of

40. Prayer Books, 347.

41. The Book of Common Prayer 1559: The Elizabethan Prayer Book, ed. John E. Booty (Charlottesville, Virginia: University of Virginia Press for the Folger Shakespeare Library, 1976), 48.

42. Prayer Books, 212. 
the earlier books, except for a connecting "and."

The body of our Lord Jesus Christ which was given for thee, preserve thy body and soul into everlasting life: and take and eat this, in remembrance that Christ died for thee, and feed on him in thy heart by faith, with thanksgiving. . . . The blood of our Lord Jesus Christ which was shed for thee, preserve thy body and soul into everlasting life: and drink this in remembrance that Christ's blood was shed for thee, and be thankful. ${ }^{43}$

The Acts of Supremacy and Uniformity were followed by sets of injunctions and visitation articles which were intended to enforce the new religious policy. In addition to the normal provisions for enforcement of the settlement, the injunctions directed that sermons should be preached once a month in local churches, and that the priest responsible should "preach in their own persons" at least once a quarter, although at these time they could choose to read from a collection of homilies approved by the queen. ${ }^{44}$ The injunctions also contained several provision concerning images. Article II directed that "they shall not set forth or extol [the dignity of] any images, relics or miracles." Article XXIII directed that "they shall take away, utterly extinct, and destroy all shrines, coverings of shrines, all tables, candelsticks, ... and all other monuments of feigned miracles, pilgrimages, idolatry, and superstition." Two other directions were given near the end of the injunctions. The first provided for the orderly removal of altars, "wherein no riotous or disordered manner to

43. Emphasis added. Prayer Book of 1559, 264.

44. This provision appears in Article III of the Injunctions. "The Royal Injunctions of 1559" in Gee, The Elizabethan Clergy, 46-47. 
be used," and that the Communion table be placed where the altar had previously stood except during Communion services. The second provided for the use of wafers as the communion bread. ${ }^{45}$ The Articles of Inquiry contained no similar surprises. They were just a very detailed list of the prohibited practices the royal visitors were to investigate. ${ }^{46}$

The Convocation of 1563 followed the initial steps in England's return to Protestantism by approximately four years. It was as significant for what it did not do, as for what it did do, as Haugaard asserts. ${ }^{47}$ It did not accede to the petitions and pressures of the more zealous reformers in the Lower House. It did not approve certain documents submitted by the more zealous reformers in the Upper House. ${ }^{48}$ It did approve the Thirty-nine Articles of Religion, which seem to have reflected the theology of the moderate reformers, the privy councilors and Elizabeth, herself. It also adopted a Catechism for educating both clergy and laity, and approved the publication of a second Book of Homilies. ${ }^{49}$ This combination of actions by the Convocation clearly defined the

45. This last provision was in direct conflict with the rubric in the Prayer Book of 1559 which provided that "the bread be such as is usual to be eaten at the table with other meats." "The Royal Injunctions of 1559," in Gee, The Elizabethan Clergy, 46-65; The Prayer Book of 1559, 267.

46. "Articles of Inquiry, 1559," in Gee, The Elizabethan Clergy, 65-70.

47. Haugaard, Elizabeth and the English Reformation, viii.

48. Haugaard, Elizabeth and the English Reformation, 342-56.

49. The first Book of Homilies had been published in 1547. Certain Sermons or Homilies appointed to be read in Churches in the Time of the Late 
limits of Elizabethan Protestantism, although it would be several years before that fact would be clear to the more zealous reformers.

A number of issues came to the fore during the fifteen years following the Convocation of 1563 , most notably the disputes over images and vestments or habits, and the merits of prophesying. The issue of images in places of worship actually pre-dated the convocation by several years. In 1559 Richard Cox respectfully refused to preside at the Mass in the queen's chapel because she had a crucifix and two lighted tapers on her altar. The question was whether that practice was idolatrous or contributed to the continued encouragement of superstitious beliefs concerning the Mass. The debate continued with a disputation between Matthew Parker and Cox, on the one hand (remarkably, defending the presence of those images in the queen's chapel), and Edmund Grindal and John Jewel, on the other. And, even after the disputation was concluded without anyone really winning or losing, the debate still continued in the country at large. ${ }^{50}$

The debate over vestments or habits was another aspect of the theme regarding images: namely, whether it was desirable for worship to be as simple as possible. Most of the reformers believed that only through simplicity could

Queen Elizabeth, ed. anon. (Oxford: Oxford University Press, 1840), iii-iv.

50. The disputation had no effect on the presence or absence of images. The problem of iconoclasm persisted, and, with it, the debate over what actions were appropriate in the removal of images. 
there be some assurance that the church was really basing its liturgy strictly on Scripture, eliminating superstition, and returning to the more pure form of the early apostolic church. Only through simplicity could there be some assurance that the common people were not being misled or distracted from the central theme of the Word of God in Scripture.

The debate concerning vestments or habits actually started during the reign of Edward VI. In 1551 John Hooper resisted the requirement that he wear a certain set of fairly elaborate vestments for his consecration as Bishop of Gloucester in 1551. After a protracted battle of wills and a short imprisonment in the Fleet, he agreed to wear the vestments for his consecration, provided that he would not have to wear them while serving as bishop in the diocese of Gloucester. ${ }^{51}$ The issue resurfaced in Elizabeth's reign.

The other issue which received significant attention during the first half of Elizabeth's reign was the merits of prophesyings. Patrick Collinson describes prophesyings as public expositions of the Bible which involved "a gathering of clergy for collective edification through the preaching of two or three sermons on the same passage of Scripture. Most of Elizabeth's bishops viewed them as a means of training clergy to preach. ${ }^{52}$ The more zealous reformers saw them as

51. Jasper Ridley, Thomas Cranmer (Oxford: Clarendon Press, 1962), 314; Dickens, The English Reformation, 264; Cuming, Anglican Liturgy, 71.

52. Patrick Collinson, Archbishop Grindal, 1519-1583: The Struggle for a Reformed Church (Berkeley, California: University of California Press, 1979), 1516, 234. 
a means of identifying the gift of prophecy in individuals. Those individuals were then deemed fit to be called to preach the Gospel. ${ }^{53}$

Elizabeth viewed prophesyings differently from either her bishops or the more radical reformers. She saw those exercises as an opportunity for those who opposed established church doctrine to present nonconforming theological beliefs in public, thereby encouraging nonconformity. Also, where episcopal discipline was lax, as it was alleged to be in Norwich, prophesyings provided an opportunity for suspended clergy to spread their nonconformist doctrine.

Therefore, early in 1574 Elizabeth directed Matthew Parker, the archbishop of Canterbury, to require each of the bishops of his province to suppress all vain prophesyings. ${ }^{54}$ But that was not the end of the debate or of prophesyings. They continued at least until 1576, when they became the cause of a confrontation between Elizabeth and her new archbishop, Edmund Grindal. ${ }^{55}$

The positions individuals took on the issues of images, vestments, and prophesyings were based on their theology, even though the issues were not primarily theological. There were three theological questions which tended to differentiate individual positions on religious issues. The theological questions

53. Walter H. Frere, The English Church in the Reigns of Elizabeth and James I. (1558-1625) (London: Macmillan and Co., 1904), 186.

54. Queen Elizabeth to Parker, 25 January 1564, in Matthew Parker, Correspondence of Matthew Parker, ed. John Bruce (Cambridge: Cambridge University Press, 1853), 223-27.

55. Collinson, Grindal, 16, 233-42. 
centered on the degree to which it was necessary for all aspects of faith and worship to be based on Scripture, the doctrine of predestination versus free will, and the doctrine of the Eucharist regarding the nature of the elements of bread and wine.

The central themes of Protestant theology were the emphasis on Scripture as the sole authority for truth, and the doctrines of justification by faith alone and predestination. The emphasis on Scripture led to the simplification of worship, so that the worshiper could focus on the Word of God as revealed in Scripture and sermons. The Scripture readings, as well as all prayers and the sermon, were to be clearly audible to the people in a language they could understand. Simplification of the liturgy included the removal of all images and ornaments from churches, and the removal of most congregational participation and most music from the liturgy. Also, the minister was not to wear elaborate vestments, not even a surplice.

The doctrine of justification by faith alone, which had been developed most notably by Martin Luther, asserted that an individual's salvation was based on his acceptance of Jesus Christ as his personal Savior, and did not require the reception of God's grace through sacraments administered by priests of the church or through other good works. The Catholic Church asserted that man could exercise his own free will to work for his own salvation through good works, including the reception of the sacraments. The reformers countered with 
two new doctrines, based on their reading of Scripture. One was justification by faith alone. Luther said:

The Word of God cannot be received and cherished by any works whatever but only by faith. Therefore it is clear that, as the soul need only the Word of God for its life and righteousness, so it is justified by faith alone and not any works. ${ }^{56}$

Therefore, the primary purpose of worship was to enable the worshiper to enter God's presence, so that all who sought him might come to know and believe in Christ. This also contributed to the desire to simplify the liturgy. The Eucharist became less significant. The remembrance of Christ's death and resurrection, and the Eucharist as a means of entering into communion with Christ, were still a key part of worship. But the Eucharist and the other sacraments were no longer seen as the sole source of God's grace, necessary to salvation. Worship was intended primarily to help the people hear and understand the Word of God, through Scripture, sermons, and prayers.

The second doctrine, which was presented in opposition to the doctrine of free will, was predestination. Luther believed that the foreknowledge of God and God's unceasing omnipotence were essential to the Christian faith. These facts led to his assertion that man cannot exercise his free will with respect to spiritual matters. He said, "If we believe it to be true that God foreknows and predestines all things, ... then on the testimony of reason itself there cannot be

56. Martin Luther, "The Freedom of a Christian," in Martin Luther: Selections from his Writings, ed. John Dillenberger (Garden City, New Jersey: Doubleday and Co., 1961), 55. 
any free choice in man or angel or any creature." ${ }^{157}$ Luther wrote his treatise on free will in 1525 in response to a document on the same subject authored by Erasmus one year earlier. Erasmus, in his treatise, acknowledged that Scripture contained some evidence in support of the enslavement of the will, but he felt that there was sufficient evidence to assert that man had at least sufficient free will to decide whether to accept or reject God's grace. He asserted that "in consenting, grace and the human will act together, but in such a way that grace is the principal cause, and the secondary cause our will ... a good will cooperates with the action of grace. ${ }^{118}$ This was the position which Richard Cheyney would espouse approximately 45 years later, in a set of sermons delivered in Bristol in the late summer of $1571 .^{59}$

The doctrine of the Eucharist may have been the primary point of contention in England during the Edwardian phase of the Reformation. By that time there appear to have been four different theories or doctrines regarding the real presence of Christ in the Sacrament: transubstantiation, consubstantiation, virtualism (or spiritual Real Presence), and memorialism.

57. Martin Luther, "On the Bondage of the Will," in Luther and Erasmus: Free Will and Salvation, ed. and trans. Philip S. Watson (Philadelphia: Westminster Press, 1969), 122, 243, 332.

58. Erasmus, "On the Freedom of the Will," in Luther and Erasmus: Free Will and Salvation, trans. and ed. E. Gordon Rupp (Philadelphia: Westminster Press, 1969), 54-64, 80-81.

59. Strype, Annals, Vol. 1, Part 2, 279. 
Transubstantiation, the Catholic doctrine, asserted that the bread and wine were transformed into the Body and Blood of Christ "at the moment of the consecration," but that their outward signs were not changed. They still looked, smelled, tasted and felt like bread and wine. The change could only be detected through faith. Consubstantiation was Martin Luther's explanation of the real presence. He stated that Christ's body and blood are present in the Eucharistic elements through God's grace and power, not through any action by the priest. ${ }^{60}$ Virtualism was the belief that, although the bread and wine are unchanged during the consecration, the faithful communicant receives Christ spiritually. This may have been Cranmer's theory of the Eucharist at the time of the publication of the first Prayer Book. In his Defence of the True and Catholic Doctrine of the Sacrament, Cranmer asserted that

As with our corporal eyes, corporal hands, and mouths, we do corporally see, feel, taste, and eat the bread and drink the wine, being signs and sacraments of Christ's body, even so with our spiritual eyes, hands, and mouths, we do spiritually see, feel, taste, and eat his very flesh and drink his very blood. ${ }^{61}$

Memorialism asserted that Christ could not really be present in the elements of the Eucharist. He was in heaven. The Eucharist was a celebration in commemoration of Christ's death and resurrection.

60. Martin Luther, "The Freedom of a Christian," 235.

61. Thomas Cranmer, "Defence of the True and Catholic Doctrine of the Sacrament, 1550," in The Work of Thomas Cranmer, ed. G. E. Duffield (Philadelphia: Fortress Press, 1965), 208-209. 
The Elizabethan bishops had all been influenced by the Reformation. The works of Martin Luther were known and read by students at Oxford and Cambridge, beginning in approximately $1524 .^{62}$ All the Elizabethan bishops were students either then or later, and all entered the priesthood during either Henry VIII's or Edward VI's reign. In fact the three bishops discussed in this thesis probably accepted some aspects of Protestant theology while they were students. ${ }^{63}$ In addition, two of the three, Cox and Parkhurst, had lived in exile during Mary's reign and had experienced simplified forms of worship on the continent. Even Cox, who had helped author the first two English Prayer Books, had been required by the magistrates of Frankfurt to make some simplifying modifications to the Prayer Book of 1552 .

62. John Longland, bishop of Lincoln, to Wolsey, from Holborn, in Original Letters Illustrative of English History, Third Series, Vol. 2, ed. Henry Ellis (182446; reprint, London: Dawsons of Pall Mall, 1969), 77-80; Ridley, Cranmer, 20-21.

63. There is clear evidence concerning both Cox and Parkhurst, as will be demonstrated below. The evidence concerning Cheyney is less definite. 


\section{CHAPTER III}

\section{THE CONVOCATION OF 1563}

The definition of the Elizabethan Settlement had begun in 1559 in the meetings of Parliament and had continued through a series of injunctions and diocesan visitations. However, many people believed that the form of religion defined in 1559 was just the first step toward Protestantism. Norman Jones says,

It was understood that the 1559 settlement was an interim during which the nation was to be readied for the completion of the reformation. Not until Convocation met in 1563 did it become apparent that Elizabeth had no intention of going beyond the 1559 settlement. ${ }^{64}$

The Protestants wanted more reforms and they hoped to achieve their goal in the Convocation of 1563.

Historically, convocations of the church in England had been dominated by the Upper House (i.e., the bishops), and the meeting in 1563 was no exception. ${ }^{65}$ Further, most of the members of the Upper House in 1563 had

64. Jones, Faith by Statute, 169-70.

65. Edmund Gibson, Synodus Anglicana, (1702), 112, cited in Haugaard, Elizabeth and the English Reformation, 59. 
been appointed by Elizabeth. ${ }^{66}$ Their primary goal appears to have been a clearer definition of doctrine, and the result was the approval of the Thirty-Nine Articles of Religion. ${ }^{67}$ However, the process of achieving that end involved heated debate between those who favored the Settlement of Religion as it had been defined and refined during the first four years of Elizabeth's reign, those who preferred Henrician Catholicism, and those who wanted a church more closely aligned with Calvinism.

On 28 April 1562 John Parkhurst wrote to Henry Bullinger that he hoped that the state of religion in England would be improved as a result of the impending convocation. ${ }^{68}$ Others were also hoping for additional reforms.

Five documents proposing reforms were prepared for consideration by the Upper House. Edwin Sandys, bishop of Worcester, submitted proposals concerning liturgical and canonical changes, and clerical orders. William Alley, bishop of Exeter, in an address which apparently was to be delivered to the Upper House, discussed doctrinal issues, including vestments and other clerical attire, and administrative and legal issues. In addition a paper titled "Certain

66. Only Thomas Davies of St. Asaph and Anthony Kitchin of Llandaff had been appointed to their sees prior to Elizabeth's accession. Haugaard, Elizabeth and the English Reformation, 47. Please see Appendix A for a list of the bishops of the Church of England in 1563.

67. Jones, Faith by Statute, 170.

68. Parkhurst to Bullinger, from Ludham, 28 April 1562, in Zurich Letters, Vol. 1, 108. 
Articles in substance desired to be granted by the queen's majesty" was submitted anonymously. This paper urged reforms on a wide range of issues and seems, based on the tone of the language used, to have been drafted by one or more of the more zealous reformers. ${ }^{69}$ The fifth document prepared for consideration by the Upper House was titled, "General notes of matters to be moved by the clergy in the next Parliament and synod." This document apparently covered the following topics:

I. "A Certain form of doctrine"

II. "Concerning Certain Rites, etc."

III. "Ecclesiastical Laws and Discipline"

A. "Concerning the Clergy"

B. "Touching the Discipline of the Laity"

IV. "The Supply of . . . small benefices"

Five other documents are extant which seem to have been prepared in the Lower House during the course of the Convocation. "The Thirty-nine Articles of Religion" was a revised version of the "Forty-two Articles of Religion"

69. Strype asserts that the "Certain Articles" were drafted by one of the secretaries to the archbishop, and amended by the archbishop and Bishop Grindal. However, Haugaard believes that, although Strype may have correctly identified the hands evident in the manuscript, the surviving manuscript was probably a copy of the original and therefore does not prove the authorship of the document. Strype, Annals, Vol. 1, Part 1, 500, 506-507, 518-25; Haugaard, Elizabeth and the English Reformation, 342-45.

70. Haugaard presents a very careful analysis of this document and of Strype's presentation of it. There has been some confusion as to its contents and the order of the sections within the document. Haugaard, Elizabeth and the English Reformation, 346-52. 
of $1553 .^{71}$ The "Seven Articles" and the "Six Articles" both seem to have been sets of proposals to simplify ceremonies beyond the provisions of the Thirty-nine Articles or the Prayer Book of 1559. "Articles for Government" dealt with administrative matters and probably were drafted with Archbishop Parker's approval. Finally, the "Twenty-one Articles" focused on enforcement of doctrine. $^{72}$

The Convocation began on 13 January 1563 at St. Paul's Cathedral in London with Matthew Parker, archbishop of Canterbury, presiding. All of the bishops of the Province of Canterbury were present except Anthony Kitchen of Llandaff, who was near death and remained in his diocese. ${ }^{73}$ In the third session, held on Saturday, January 16, Alexander Nowell, the dean of St. Paul's, was elected prolocutor of the Lower House. Substantive work appears to have actually begun on January 19 in the fourth session, when debates and discussions began on the Articles of Religion. ${ }^{74}$

71. Charles Hardwick, A History of the Articles of Religion to which is added a Series of Documents from A.D. 1536 to A.D. 1615 (London: George Bell and Sons, 1904), 289-353, 391-420; Strype, Annals, Vol. 1, Part 1, 484-91; Haugaard, Elizabeth and the English Reformation, 352-53.

72. Strype, Annals, Vol. 1, Part 1, 500-12; Strype, Annals, Vol. 1, Part 2, 562-68; Haugaard, Elizabeth and the English Reformation, 352-56.

73. Cardwell, Synodalia., Vol. 2, 497-99. Kitchen died on approximately 31 October 1563. Haugaard, Elizabeth and the English Reformation, 1.

74. Cardwell, Synodalia, Vol. 2, 495-97, 499, 506-508; John Strype, The Life and Acts of Matthew Parker, Vol. 1, (Oxford: Clarendon Press, 1821), 240-42; Strype, Annals, Vol. 1, Part 1, 471-72, 484-85. 
The Thirty-nine Articles of Religion, which were debated and ultimately approved by this convocation, were based on the Forty-two Articles, which had been prepared and promulgated at the end of the reign of Edward VI. ${ }^{75}$ The earlier set of articles were drafted by a commission which was headed by Thomas Cranmer and included Matthew Parker, Peter Martyr, Richard Cox, and William Cecil. ${ }^{76}$ Those articles were in turn probably based on a set of Thirteen Articles drafted in 1538 by a group of German and English divines. At that time Henry VIII was attempting to enter into an alliance with the German princes. The Thirteen Articles may have been intended to serve as a negotiating tool. $^{77}$

The Thirty-nine Articles of 1563 appear to have been an attempt to clearly define the boundaries of conformity by addressing issues which were

75. The Forty-Two Articles of Religion were never presented to Convocation for approval. They were submitted to the Privy Council in May 1552 and promulgated by the king on 12 June 1553. C. W. Dugmore, "Foundation Documents of the Faith; VI. The Thirty-nine Articles," Expository Times, 91 (March, 1980): 165.

76. Acts of the Privy Council of England. New Ser. Vol. 3. A.D. 15501552, ed. John R. Dasent, (London: Eyre and Spottiswoode, 1891), 382. Peter Martyr (Vermigli) was a former Italian Austin Friar who had fled to Zurich and then Strassburg before coming to England. He had arrived in England in 1547, and was named regius professor at Oxford in the spring of 1548. M. A. Overall, "Peter Martyr in England, 1547-1553: An Alternative View," Sixteenth Century Journal, 15 (Spring, 1984): 87. Sir William Cecil, who became Lord Burghley under Elizabeth, had served Tudor monarchs from the latter part of the reign of Henry VIII, including Mary. He was Elizabeth's most trusted advisor. Dictionary of National Biography.

77. Dugmore, "The Thirty-nine Articles," 164. 
matters of doctrine or at least desirable goals for non-conformists, either papists or reformers. Article VI declares that "Holye Scripture conteyneth all thinges necessarie to saluation." Article IX addresses the doctrine of original sin and Article $\mathrm{X}$ addresses free will. Justification by faith alone is asserted in Article XI and good works as the results of faith are discussed in Article XII. Works of supererogation are criticized in Article XIII. Predestination and election are discussed in Article XVII. Article XXII says,

The Romish doctrine concerning purgatorie, pardons, worshipping and adoration as well of images, as of reliques, and also inuocation of Saintes, is a fonde thing, vainly inuented, and grounded vpon no warrantie of Scripture, but rather repugnaunt to the worde of God."

Article XXIV criticizes the use of "a tongue not vnderstanded of the people" as "playnely repugnaunt to the worde of God." Article XXV identifies the sacraments which are based on Scripture and clearly labeled others as "not to be compted for Sacramentes of the gospel." Article XXVIII rejects transubstantiation and affirms the spiritual presence. Article $\mathrm{XXX}$ rejects the Mass as a sacrifice. Most of these, except Article IX which discusses original sin, appear to have been intended to refute Catholic doctrine. Article IX and Article XXXVII, which declares that "the ryches and goodes of Christians are not common," appear to be directed at the radical reformist sect known as the Anabaptists. Actually, a number of other articles also seem to attack Anabaptist 
doctrine, although less directly. ${ }^{78}$

The process of drafting, revising, and agreeing on the Thirty-nine Articles was concluded on January 29. Probably, all but one of the bishops and many of the Lower House subscribed. Cox of Ely and Parkhurst of Norwich are clearly listed among the subscribers. There appears to have been some confusion concerning Cheyney of Gloucester and Bristol. Strype asserts that according to "certain extracts, out of the registers of convocations, that bishop did subscribe, his name being here among the rest."179 However, since Strype does not clearly identify his source, his assertion can not be proven. Given Cheyney's later actions, it seems highly unlikely that he subscribed to the Articles at this time. ${ }^{80}$ Having concluded the task of defining the doctrine of the Church of England, the Convocation then turned to the approval of a Second Book of Homilies, the consideration of liturgical changes, and the adoption of a catechism.

The first Book of Homilies had been published early in the reign of Edward VI, as a means of combating the shortage of priests qualified to preach the Gospel. The preface to the second book sounded a similar theme.

Considering how necessary it is, that the word of God, which is the only food of the soul, and that most excellent light that we must walk

78. Hardwick gives a thorough analysis of the source and intent of each of the articles in his notes. Hardwick, Articles, 291-347, 391-420.

79. Strype, Parker, Vol. 1, 243; Strype, Annals, Vol. 1, Part 1, 487.

80. Richard Cheyney's position on the Thirty-nine Articles will be discussed in detail in Chapter IV, below. 
by in this our most dangerous pilgrimage, should at all convenient times be preached unto the people, ... and also to avoid the manifold enormities which heretofore by false doctrine have crept into the church of God; and how that all they which are appointed ministers have not the gift of preaching . . . the queen's most excellent majesty . . . caused a book of homilies [to be printed]. ${ }^{81}$

Article XXXIV in the Articles of Religion listed the titles of the homilies contained in the Second Book of Homilies:

Of the right vse of the Churche.

Agaynst perill of Idolatrie.

Of repayring and keping cleane of Churches.

Of good workes, first of fastyng.

Agaynst gluttony and drunkenesse.

Against excesse of apparell.

Of prayer.

Of the place and time of prayer.

That common prayers and Sacramentes ought to be ministred in a known tongue.

Of the reuerente estimation of Gods worde.

Of almes doing.

Of the Natiuitie of Christe

Of the passion of Christe.

Of the resurrection of Christe.

Of the worthie receauing of the Sacrament of the body and blood of Christe.

Of the gyftes of the holy ghost.

For the Rogation dayes.

Of the state of matrimonie.

Of repentance.

Agaynst Idlenesse.

Agaynst rebellion. ${ }^{82}$

Two homilies stand out from all the others. The homily, titled "Against

Peril of Idolatry, and superfluous Decking of Churches" and that titled, "Against

81. Certain Sermons or Homilies, xiii.

82. Hardwick, Articles, 339, 341. 
Disobedience and wilful Rebellion" are much longer than any of the others. ${ }^{83}$ A fairly lengthy homily intended to discourage rebellion makes a great deal of sense. However, the homily against idolatry is really arguing against images in churches. It is remarkable that this homily was allowed in the book at all, and its length is all the more remarkable.

In the homily against idolatry the author or authors take pains to assert that images in churches are forbidden by the second commandment and that in particular "images of Christ, be not only defects, but also lies." This homily goes on to specifically admonish, not only bishops and priests, but Christian princes as well.

For ye have heard it evidently proved in these homilies against idolatry, ... that images have been and be worshipped ... to the great offense of God's majesty, and danger of infinite souls; . . . Wherefore God's horrible wrath, and our most dreadful danger cannot be avoided, without the destruction and utter abolishing of all such images and idols out of the church and temple of God, which to accomplish, God put it in the minds of all Christian princes. And in the mean time, let us take heed and be wise.

The other homilies do not seem to address matters of controversy. Instead, they articulate the accepted doctrine of the Church of England. ${ }^{84}$

Following the authorization of the Second Book of Homilies, Bishop

83. In the edition cited the average length of the second set of homilies is 17.5 pages. "Against Disobedience" is 44 pages long. "Against Perils of Idolatry" is 82 pages long. Certain Sermons or Homilies, 143-533 passim.

84. The reference to multiple homilies on idolatry refers to the fact that the homily was divided into three parts. Certain Sermons or Homilies, 158-68, 196, 239. 
Sandys' proposals regarding liturgical changes were apparently considered. $\mathrm{He}$ proposed:

First, That with her majesty's authority, with the assistance of the archbishop of Canterbury, according to the limitations of the act provided in that behalf, might be taken out of the Book of Common Prayer private baptism, which hath respect unto women: who, by the word of God, cannot be ministers of the sacraments, or of any one of them.

Secondly, That by like authority the collect for crossing the infant in the forehead may be blotted out: as it seems very superstitious, so it is not needful.

Thirdly, That according to order taken by her majesty's father, king Henry VIII. of most famous memory, and by the late king Edward, her majesty's brother, certain learned men, bishops and others, may by her majesty be appointed to set down ecclesiastical orders and rules in all ecclesiastical matters, for the good government of the church (sic) of England. ${ }^{85}$

Since these were presented as advice to the queen they required no action by the Convocation. However, liturgical proposals were debated and voted on by the Lower House.

The liturgical proposals considered by the Lower House were the documents titled Seven Articles and Six Articles. Each of these documents seems to have contained changes which would have further simplified worship, and would have completed the process of reforming the Church of England in the eyes of the more zealous reformers.

The Seven Articles proposed:

85. Strype, Annals, Vol. 1, Part 1, 500. 
I. That Psalms should be sung by the whole congregation or said clearly and audibly by the minster alone and that "all curious singing and playing of organs may be removed."

II. That only ministers should baptize and that they should not use the sign of the cross in baptism.

III. That kneeling to receive communion "be left indifferent to the discretion of the ordinary."

IV. "That the use of copes and surplices may be taken away."

V. That ministers not be required to wear caps and gowns.

VI. That the words in the Thirty-third article which describe the punishment for non-conformity in matters of tradition and ceremonies might be mitigated.

VII. That all saint's days and holy days "bearing the name of a creature, may, ... be clearly abrogated."

This set of Seven Articles was requested by thirty-four members of the Lower House, including Nowell, the prolocutor, but was not approved by that body. ${ }^{86}$

The Six Articles were no more successful, although the vote was much closer. These proposed the following:

I. "That all the Sundays in the year, and principal feasts of Christ, be kept holydays; and all other holydays to be abrogated.

II. That the minister read the service so that it could be heard by the congregation.

86. Haugaard corrects Strype's analysis of the list of subscribers to these articles. Strype says that thirty-three names are subscribed, but then he lists only thirty-two. Haugaard says that there were actually thirty-four and supplies the two missing names: John Peddler, dean of Wigorn, and Thomas Cole, archdeacon of Essex. Strype, Annals, Vol. 1, Part 1, 500-501; Haugaard, Elizabeth and the English Reformation, 353. 
III. That the sign of the cross be omitted from baptism.

IV. That "order of kneeling [during communion] may be left to the discretion of the ordinary within his jurisdiction."

V. That a surplice be sufficient as a vestment for the minister presiding at the Eucharist, and that the minister be required to wear some type of "comely garment or habit" when saying the service or administering the sacraments.

VI. "That the use of organs be removed." ${ }^{187}$

The last major act of this convocation was the adoption of a Catechism. It may have been the same as that which had been licensed by Edward VI shortly before his death. At least, according to Strype, it appears to have been based on that earlier Catechism. It was drafted by Alexander Nowell and edited by the clergy in Convocation before being approved. Nowell, representing the Lower House, presented it to the Upper House for its approval in the twentysecond session of the Convocation. Nowell said, in a letter to Cecil,

that for his part he had taken pains, as well about the matter of the book, that it might be consonant unto the true doctrine of the scripture, as also that the style might agree with the purity of the Latin tongue. ${ }^{88}$

The Catechism, which is attributed to Nowell, is divided into four principal sections, addressing the law and obedience, the Gospel and faith, prayer and thanksgiving, and sacraments. In the section on law and obedience,

87. Strype, Annals, Vol. 1, Part 1, 502-503.

88. Cardwell, Synodalia, Vol. 2, 522; Strype, Annals, Vol. 1, Part 1, 499$516,525-27$. 
which focuses on the Ten Commandments, the argument against images in churches is again presented. The discussion of the Apostles' Creed under the heading, the Gospel and faith, teaches that man's predestination to sin came as a result of Adam's abuse of free will. The section on prayer and thanksgiving contains nothing remarkable, although the invocation of saints is specifically discouraged. In the last section two sacraments are identified: baptism and the "Holy Supper." Further, the response concerning belief in transubstantiation asserts that "there is no need to invent any such change." The soul of the faithful communicant is nourished by Christ's body and blood through faith and the work of the Holy Ghost. The theology presented in this Catechism seems to be consistent with that expressed in the homilies and the Articles of Religion. The only real surprise is that, again, images in churches are described as seriously offensive to the Word of God. ${ }^{89}$

The only other actions taken by the Convocation pertained to the government and administration of the Church. On Wednesday, April 14, the Convocation was prorogued until October 3 after thirty-six sessions. The most important actions were the adoption of the Thirty-nine Articles of Religion, Nowell's Catechism, and the Second Book of Homilies. The proposals which were not approved were also significant. From a doctrinal point of view the Convocation had chosen to make only moderate changes in the Church of

89. Alexander Nowell, A Catechism, trans. Thomas Norton (Cambridge: Cambridge University Press, 1853), 119, 124-25, 149-50, 184, 207, 214-15. 
England. The proposals from the more zealous of the reformers had been rejected or modified and moderated. Those who hoped for additional reforms did not realize it at the time, but this Convocation defined the extent to which the Church of England would move in a Protestant direction. There would be additional minor changes, but none of significance. ${ }^{90}$ As Cardwell asserts, "To this memorable convocation, more than to any other, the reformed church (sic) of England is indebted for its existence and permanency."191

90. The Articles of Religion and the Book of Common Prayer in use in England today are very similar to those of 1571 and 1559, respectively. Cardwell, Synodalia, Vol. 2, 495; Haugaard, Elizabeth and the English Reformation, 1.

91. Cardwell, Synodalia, Vol. 2, 495n. 


\section{CHAPTER IV}

\section{RICHARD CHEYNEY}

Richard Cheyney was probably the most conservative bishop appointed by Elizabeth. There is significant debate among historians as to whether Cheyney was a Lutheran, a Henrician Catholic or a papist. ${ }^{92}$ In fact, it appears that his theology would be hard to categorize in these terms. Patrick Collinson describes him as theologically eccentric. ${ }^{93}$ He did not believe in transubstantiation, so he was not a papist; but he described himself as Erasmian on free will, so he was not a Lutheran. When the Church of England, meeting in convocation in 1571, required all those in attendance to subscribe to the Thirty-nine Articles of Religion, he was excommunicated for not attending (and not subscribing). ${ }^{94}$

92. Strype, Annals, Vol. 1, Part 2, 284; Gilbert Burnet, The History of the Reformation of the Church of England, Vol. 3, ed. E. Nares (London: Reeves and Turner, 1880), 474; Basil Hall, "The Early Rise and Gradual Decline of Lutheranism in England (1520-1600)" in Reform and Reformation: England and the Continent c.1500-c.1750, ed. Derek Baker (Oxford: Basil Blackwell, 1979), 13031; F. O. White, Lives of Elizabethan Bishops of the Anglican Church (London: Skeffington and Son, 1898), 176-77.

93. Patrick Collinson, The Religion of Protestants: The Church in English Society 1559-1625 (Oxford: Clarendon Press, 1982), 55.

94. All of these attributes will be discussed in detail below. For his stand on transubstantiation see John Foxe, The Acts and Monuments of John Foxe, Vol 6, ed. Stephen R. Cattley (London: R. B. Seeley and W. Burnside, 1838), 396-407; for his position on free will see Strype, Annals, Vol. 1, Part 2, 278-80; for the events of 1571 see Cardwell, Synodalia, Vol. 2, 528-30. 
Very little is known about Cheyney's early life. Born in London in about 1513, he was educated at Christ's College, Cambridge. There, he was a contemporary of John Cheke, and was influenced by Cheke's opinion concerning the correct pronunciation of the Greek language. ${ }^{95}$

John Cheke was one of the Cambridge scholars who had adopted the Erasmian pronunciation of Greek. This pronunciation differed from the medieval pronunciation then being taught in the University. It was based on Erasmus' analysis, published in 1528 , of the pronunciation used by the ancient Greeks. Cheke and a fellow scholar, Thomas Smith, took up the new or rediscovered pronunciation as a cause and began to attract followers from among the younger scholars. Eventually, Cheke was named regius professor of Greek (a new position).

Unfortunately for Cheke and his supporters, Stephen Gardiner, conservative bishop of Winchester and chancellor of the University, was not pleased by Cheke's success. The issue obviously went much deeper than a scholarly dispute over the pronunciation of an ancient language. Gardiner was a Henrician Catholic. His predecessor as chancellor at Cambridge was Thomas Cromwell, who was probably a Lutheran. Gardiner had lost influence with Henry while Cromwell was in power. The dispute over the pronunciation of Greek was apparently a part of the struggle by Gardiner to regain the position

95. DNB; C. H. Cooper, Athenae Cantabrigienses, Vol. 1 (Cambridge: Deighton and Bell, 1858), 400. 
of influence he had previously lost to Cromwell. Also, Cheke's professorship represented a change in the University curriculum that would accommodate at least one aspect of the new humanist learning. Gardiner would probably have agreed with Cardinal Wolsey and Sir Thomas More that humanist teachings needed to be limited in order to limit the spread of Protestant ideas. ${ }^{96}$ As a result, Gardiner intervened to stop the spread of the new pronunciation, and beginning in 1544 he required students to swear obedience to the University chancellor and vice-chancellor.

Association with Cheke on this issue would probably therefore tend to categorize one as a reformer. What is probably more accurate is that those who supported the Erasmian pronunciation of Greek, including Richard Cheyney, were more open to new ideas than those who did not. ${ }^{97}$

Cheyney's theology during his years as a student remains a mystery. He received his Bachelor of Arts degree from Christ's College in 1529 and was elected a fellow of Pembroke Hall in 1532. Bishop Stokesley of London ordained him subdeacon on 24 February 1532, and priest on September 21 of the same year. Cheyney received his Master of Arts degree in 1532, and his Bachelor of Divinity in 1540 . Over the next few years he received several

96. Joan Simon, Education and Society in Tudor England (1966; reprint, Oxford: Alden Press, 1979), 145-46.

97. Winthrop Hudson, The Cambridge Connection and the Elizabethan Settlement of 1559 (Durham, North Carolina: Duke University Press, 1980), 43-55. 
benefices: Maids Moreton in Buckinghamshire; Bishop's Hampton in Herefordshire; Painswick in Gloucestershire; and Halford in Warwickshire. The first three were apparently rectories. The last was a vicarage. It is not known whether he held more than one of these at any one time. ${ }^{98}$

Cheyney's theology became a little clearer in the reign of Edward VI. He became archdeacon of Hereford on 3 February 1552, and was named "one of the keepers of the spiritualities" of the diocese of Hereford while that see was vacant following the death of Bishop Skip. ${ }^{99}$ These promotions would seem to indicate that he had accepted the Edwardian Reformation, which at that point was becoming less theologically ambiguous. The second Prayer Book had not yet been issued, but the well-documented theological debate between Thomas Cranmer and Stephen Gardiner had been going on for some time. ${ }^{100}$ Also, Northumberland's control of the government had begun to move the Church of England in a more clearly Protestant direction.

Shortly after the death of Edward VI, Richard Cheyney did have an opportunity to clarify his own theology with respect to the Eucharist. A

98. DNB; Cooper, Ath. Cant., Vol. 1, 400.

99. Cooper, Ath. Cant., Vol 1, 400.

100. This debate tended to clarify Cranmer's position, which was much more Protestant than the first Prayer Book and the various injunctions and visitations would have indicated. In particular, by this time Cranmer had clearly described his own theory of the Eucharist. He acknowledged the spiritual presence of Christ in the sacramental elements for those who truly believe. Cranmer, "Defence" in Work, 208-209, 227. 
Convocation of the Province of Canterbury was convened on 13 October 1553, with orders from Queen Mary to hold a disputation on the Real Presence of Christ in the Sacrament of the Altar, and, more specifically, on transubstantiation. ${ }^{101}$ Burnet says,

There had been care taken that there should be none returned to the convocation but such as would comply in all points [with papist beliefs]. But yet there came six non-compliers, who, being deans or archdeacons, had a right to sit in the convocation. These were Philpot, archdeacon of Winchester; Philips, dean of Rochester; Haddon, dean of Exeter; Cheyney, archdeacon of Hereford; Ailmer, archdeacon of Stowe; and Young, chanter of St. David's. ${ }^{102}$

Apparently Young soon left, but the others, and especially Cheyney, entered vigorously into the disputation which began on October $18 .^{103}$ Two questions for debate were proposed by the prolocutor, Master Weston:
"Whether in the sacrament, upon the sanctification of the bread and wine, all their substance did not vanish, being changed into the body and blood of Christ? and,
Whether the natural body of Christ was not corporally present in the eucharist, either by the transubstantiation of the elements into his body and blood, or by the conjunction of concomitance, as some expressed it?"104

On Monday, October 23, Cheyney spoke, denying transubstantiation. He said,

"I would gladly my doubts to be resolved, which move me not to believe in transubstantiation. The first [doubt] is out of St. Paul of the Corinthians, who, speaking of the sacrament of the body and

101. Cardwell, Synodalia, Vol. 2, 425-26.

102. Burnet, Reformation, Vol. 2, 407-408.

103. Foxe, Acts and Monuments, Vol. 6, 396.

104. Burnet, Reformation, Vol. 2, 408. 
blood of Christ, calleth it oftimes bread, after the consecration. The second is out of Origen, who, speaking of this sacrament, saith, that the material part thereof goeth down to the excrements. The third is out of Theodoret, who, making mention of the sacramental bread and wine after the consecration, saith, that they go not out of their former substance, form, and shape. These be some of my doubts, among many others, wherein I require to be answered."105

Several days later Watson, the prolocutor, challenged Cheyney's previous statements about the Real Presence. Cheyney responded that they had misunderstood him. He said,

"The similitude of Theodoret is this . . . As the tokens of Christ's body and blood, after the invocation of the priest, do change their names, and yet continue the same substance; so the body of Christ, after his ascension, changed its name, and was called immortal, yet had it its former fashion, figure, and circumscription; and, to speak at one word, the same substance of his body. Therefore, ... if, in the former part of the similitude, you deny the same substance to continue, then, in the latter part of the similitude, which agreeth with it, I will deny the body of Christ, after his ascension, to have the former nature and substance. But that were a great heresy; therefore it is also a great heresy to take away the substance of blood (sic) and wine after the sanctification."106

Later Cheyney asked the others what was burned when the consecrated elements from the Mass were burned. "Master Watson said, 'We must not inquire nor ask, but that if there were any fault, impute it to Christ." But Cheyney persisted, asking, "'Whereof came those ashes-not of substance? or can any substance arise of accidents?" Yet again Cheyney asked what had been

105. Foxe, Acts and Monuments, Vol. 6, 397.

106. The word "blood" also appears in the 1843 edition of Foxe's work, although in this context it appears that "bread" would be the more likely word. Foxe, Acts and Monuments, Vol. 6, 406. 
burned. He asserted, "It was either . . . the substance of the bread, or else the substance of the body of Christ, which were too much absurdity to grant." Foxe reports, "At length they answered, that it was a miracle; whereat master Cheyney smiled, and said that he could say no more."107

Cheyney seemed to be clearly convinced that transubstantiation did not take place in the Mass. But, just as clearly, he indicated he believed in the Real Presence. This has led several historians to attribute a Lutheran theory of the Eucharist to him. However, the debate described above does not make that clear. He could have believed in the spiritual Real Presence espoused by Cranmer and Ridley. In any case, as a result of this disputation he was apparently deemed safe enough to be allowed to continue to maintain his clerical status during Mary's reign. ${ }^{108}$ In fact, he was one of the few Elizabethan bshops who had not gone into hiding or lived in exile on the continent during that reign. ${ }^{109}$ However, it is not clear that he had actually functioned as a priest

107. Foxe, Acts and Monuments, Vol. 6, 407.

108. He did retire to Halford in the diocese of Worcester, which was exempt from heresy persecutions, during part of Mary's reign. Also, it appears that Mary found his views on the Eucharist to be less offensive than those of the leading reformers, such as Cranmer. DNB.

109. Thomas Davies, bishop of St. Asaph, served as a priest under Mary. William Downham, bishop of Chester, served as Elizabeth's chaplain. Thomas Bentham, bishop of Litchfield and Coventry, and Edmund Scambler, bishop of Peterborough, each spent a portion of Mary's reign as minister to the Protestant congregation in London. Matthew Parker, Edmund Guest, and William Alley, bishop of Exeter, all lived in hiding in England. All the other Elizabethan bishops lived in exile on the continent. DNB. 
then. Strype records the fact that he was accused later of having been present at Mass during Mary's reign. White uses this accusation as proof that Cheyney had not functioned as a priest at that time. He says, "Presence at Mass . . . does not seem to include the idea of celebration, but to contradict it," and attendance, as opposed to celebration, does not necessarily imply acceptance of the theology embodied in the worship. ${ }^{110}$ Cheyney had resigned his archdeaconry by 1557 , but on 14 November 1558 he had become a canon of Gloucester Cathedral, having been nominated by Philip and Mary. ${ }^{111}$

Following the accession of Elizabeth to the throne, his fortunes improved. Cecil invited him to preach before the queen on 6 April $1560 .{ }^{112}$ His friends in London apparently suggested him for various preferments, but he indicated in a letter to Cecil, "I intend to make an end in mine age at the cart, at my circumcised benefice."113 However, in spite of his protestations, Elizabeth named him to a prebend-one of twelve-of the new cathedral of Westminster on 21 May 1560.114 Also, Archbishop Parker recommended him for the position of

110. Strype, Annals, Vol. 1, Part 2, 279-80; White, Lives, 172.

111. Cooper, Ath. Cant., Vol. 1, 400.

112. Winthrop Hudson notes that Cheyney and Cecil were contemporaries at Cambridge and that both were followers of Cheke. Hudson, The Cambridge Connection, 55; Strype says that Cheyney was noted "for his learning and ability to preach." Strype, Annals, Vol. 1, Part 2, 418.

113. Parker, Correspondence, 138-39.

114. He seems to have tried to decline the appointment, pointing out that he was not willing to reside in London and asserting that resident canons would be 
provost of Eton in a letter to Cecil. He was not selected. ${ }^{115}$ However, on 2 May 1562 the queen confirmed his election as bishop of Gloucester. ${ }^{116}$

Cheyney's selection to fill the see at Gloucester was probably a grave error. One historian characterized it as placing "a round man in a square hole."117 This was the diocese where John Hooper, the radical Edwardian bishop, had presided just a few years earlier. John Hooper was a Zwinglian Protestant, who had spent almost ten years with the reformers in Zurich during the last years of the reign of Henry VIII. ${ }^{118}$ He was a gifted preacher and a strong Protestant. He was nominated bishop of Gloucester on 7 April $1550 .^{119}$ His strong Protestantism led him to be highly critical of the first Prayer Book, and to resist the vestment requirement contained in the Ordinal of $1550 .{ }^{120}$ Ultimately, after a brief imprisonment in the Fleet, he was consecrated in

preferable. Strype, Annals, Vol. 1, Part 1, 418; Calendar of Patent Rolls, Elizabeth, Vol. 1, 397.

115. Strype, Annals, Vol. 1, Part 1, 374.

116. Cal. of Patent Rolls, Elizabeth, Vol. 2, 403.

117. White, Lives, 174-75.

118. W. K. Jordan, Edward VI: Threshold of Power (London: George Allen and Unwin, 1968), 283.

119. Martyr to Bullinger, from Oxford, 28 January 1551, Martin Micronius to Bullinger, from London, 20 March 1550, in Original Letters, ed. Hastings Robinson (Cambridge: Cambridge University Press, 1846), 487, 559.

120. Hooper to Bullinger, from London, 27 March 1550, in Original Letters, ed. Robinson, 79; Prayer Books, 313. 
vestments in March 1551. ${ }^{121}$ Hooper had undoubtedly been the most radical of the Edwardian bishops, and his successor in Gloucester was the most conservative of the original Elizabethan bishops.

Richard Cheyney's problems as bishop began soon after he was given responsibility for Bristol, as well as Gloucester. He was granted the bishopric of Bristol in commendam by letters patent from the queen on 29 April 1563. Then, on May 3, Archbishop Parker commissioned him "his vicar-general, delegate, and commissary general in spirituals, and keeper of the spirituality of the city and diocese of Bristol." However, Parker soon retracted this commission. ${ }^{122}$ He was probably dissatisfied with both Cheyney's theology and his diocesan administration. The removal of Bristol from his spiritual care prompted Cheyney to write to Cecil more than once, attempting to resign the bishopric of Gloucester, although he still held Bristol in commendam. He was still responsible for administering the diocese and, more specifically, for implementing the Settlement of Religion in both dioceses. However, it seems that at that time both financial and theological concerns relating to the administration of his diocese (or dioceses) troubled him. He was clearly upset by the theology espoused by preachers in both Gloucester and Bristol. In a

121. Hooper agreed to be consecrated in vestments but was not required to wear them in his own diocese after he became bishop. Dickens, The English Reformation, 242; Cuming, Anglican Liturgy, 71.

122. Strype, Annals, Vol. 1, Part 1, 419. 
letter dated 17 September 1563 Cheyney said,

I can not but renue my former sute to your Honour towchyng the resignyng of myne office, for consideryng that the iurisdiction of Bristow is taken from me, and in some poynctes suche prechyng of ye rashe and ignoraunt is continued in Gloucester diocese, as my consciens and poore learnyng can thynk not to be good, contarie to the promyse that my Lords Grace of Canterbury made me at my beyng at London: I had moche rayther lyve a private lyfe, like a poore man, as I dyd before I was drawen to office. ${ }^{123}$

He went on to complain about the subsidy owed to the queen and to express his desire to resign because of the debt, suggesting that could be accomplished if he were to resign between next Michaelmas (September 29) and "Allhaloutide" or All Saints Day (November 1).

Elizabeth did not accept his resignation, and his difficulties did not end. He also continued his association with the diocese and city of Bristol. In one instance the sermons of one Norbrook prompted him to go to Bristol and preach three sermons in response.

He preached his sermons on August 22 and 29 and on September 1 of 1568. Then on October 20 some of the citizens of Bristol wrote to Cecil to complain about the erroneous doctrine preached by the bishop of Gloucester. They enclosed a set of articles describing his alleged doctrinal errors. ${ }^{124}$ They

123. Richard Cheyney to Sir William Cecil, from Lekyngton, 17 September 1563, British Library Lansdowne Collection 6, 72 (fol. 174); printed in Original Letters, Vol. 3, ed. Henry Ellis, 353-56.

124. Cheyney to Cecil, 7 October 1568, Cheyney to Cecil, 15 October 1568, Citizens of Bristol to Cecil, 20 October 1568, in Calendar of State Papers, Domestic, Elizabeth, Vol. 48, 319-20. 
accused Cheyney of erroneous beliefs concerning Scripture, of favoring Erasmus' position on free will, and of favoring the ancient fathers over the leaders of the Protestant Reformation, such as Calvin.

The Articles were apparently excerpts from the three sermons. In discussing Scripture, Cheyney was alleged to have said, "Scripture, scriptures, do you cry? Be not too hasty: for the heretics always cried; and had the scriptures. . . . In reading the scriptures, be you like the snail ... for when he feeleth a hard thing against his horns, he pulleth them in again; so do you: read scripture . . . but when you come to matters of controversy, go back again; pull in your horns."

He was further accused of having asserted that

"Luther wrote a very ill book against free-will; wherein he did very much hurt. But Erasmus answered him very learnedly. So that I am not of Luther's opinion therein, but of Erasmus's mind."

This placed him in opposition to predestination. The Calvinists in Bristol viewed this position as heretical.

Cheyney had gone further with regard to Calvin. He had impugned the wisdom and insights of Calvin, specifically, as well as attacking the other Reformation leaders in general. He had seemed to give the leaders of the Reformation less credence than he gave the early church Fathers, because the reformers' ideas had not been tested by generations of theologians and ecumenical councils. He said,

"Be not too swift or hasty to credit these new writers, for they are not yet thoroughly tried and approved, as the catholic fathers are. . . . These new writers in matters of controversy, as Mr. Calvin and others, agree not together, . . . in matters now of controversy follow 
them not, but follow the old fathers and doctors, although Mr. Calvin denieth some of them."125

Some of the people of Bristol were clearly angered, but these statements also give a fairly clear picture of some of Cheyney's beliefs at this point in his life.

Earlier, in 1566 , Cheyney had had the opportunity to clarify his beliefs concerning the Real Presence in the Eucharist. In that year, when a bill to confirm the Articles of Religion, approved by the Convocation of 1563 , was presented in the House of Lords, "Bishop Cheyney protested against the clause in the Twenty-eighth respecting the body of Christ being given, taken and eaten in the Sacrament 'only after an heavenly and spiritual manner." According to John Jewel, bishop of Salisbury, at that time Cheyney also declared that he favored Luther's explanation of the Real Presence. ${ }^{126}$ Article Twenty-eight states that

The Supper of the Lord is not only a signe of the loue that Christians ought to haue among them selues one to another: but rather it is a Sacrament of our redemption by Christes death. . . . The body of Christe is geuen, taken, and eaten in the Supper only after an heauenly and spirituall maner: And the meane whereby the body of Christe is receaued and eaten in the Supper, is fayth. ${ }^{127}$

The underlined word, only, was apparently the problem for Cheyney. He believed that the insertion of that word at that point in the Article removed

125. Strype, Annals, Vol. 1, Part 2, 278-80.

126. White, Lives, 131-32.

127. Emphasis added. Hardwick, Articles, 329, 331. 
Christ's presence from the sacrament. This would seem to indicate that he believed in physical, rather than spiritual, Real Presence and, since he previously had refuted transubstantiation, one might conclude that he believed in consubstantiation. Edmund Guest, bishop of Rochester had added the word "only" in order "to take awaye all grose and sensible presence. .. . [But] to avoyde offence \& contention ye worde onelye maye be well left out, as not nedefull."'128

While Cheyney had clarified his theological views, he had not improved his situation in his diocese. The complaints from the citizens of Bristol were apparently considered by the Privy Council, but there is no record of any action taken against him or against his accusers. A short time later some of his supporters apparently tried to have him translated to the see of Chichester after the death of the bishop there. However, Archbishop Parker would not support that move, saying,

I would be loth it should fall upon one such body as, I am informed by his friends, make suit for it. We of this order learn by experience what rule Gloucester maketh in his people. He is so old that he would bring his people to his contemplations, which he laboureth to do, but spyeth that he shall never, and thereupon wisheth he were discharged, which he hath pretended a long time. But he meaneth another thing. ${ }^{129}$

Archbishop Parker was concerned about more than just Cheyney's

128. White, Lives, 130 .

129. Parker to Cecil, from Lambeth, 19 August 1569, in Parker, Correspondence, 332; Strype, Annals, Vol. 1, Part 2, 285. 
theology. The administration of the diocese of Gloucester also created problems. The see had been vacant for four years following the death of Cheyney's predecessor, before Cheyney had been named bishop. ${ }^{130}$ Cheyney had apparently been unable to gain control of his commissaries, and his episcopal administration was described as lax. There was an absence of clerical discipline, and the diocesan courts were evidently not being properly conducted. ${ }^{131}$ F.D. Price characterizes the Gloucester court as being extremely unpopular, because it was ineffective. He says, "It was disliked not so much for what it did as for what it did not do ... under the weak rule of Thomas (sic) Cheyney, the first Elizabethan bishop (1562-79)." It was unable to enforce its orders. In fact, it was held in such low esteem that groups of individuals and corporate bodies were willing to defy its orders and risk excommunication. ${ }^{132}$ Finally, in 1579, the chancellor of the diocese, Thomas Powell, whom Cheyney supposedly supervised, was forced to resign in disgrace. ${ }^{133}$

130. Cal. of Patent Rolls, Elizabeth, Vol. 2, 364; Roger B. Manning, "The Crisis of Episcopal Authority During the Reign of Elizabeth I," Journal of British Studies 11 (November, 1971): 13. Authority," 13.

131. Houlbrooke, "Protestant Episcopate," 93-94; Manning, "Episcopal

132. F. D. Price has done extensive research on the diocese of Gloucester. Unfortunately, in this instance he confused Richard Cheyney, the priest and bishop, with Thomas Cheyney, the privy councillor. F. Douglas Price, "The Abuses of Excommunication and the Decline of Ecclesiastical Courts under Queen Elizabeth," The English Historical Review 57 (January, 1942): 106, 109; DNB.

133. Manning characterizes Powell as being more interested in collecting fines, from which he received a portion, than in enforcing ecclesiatical discipline. 
Cheyney remained in Gloucester following the confrontation with the Puritans in Bristol. As the Convocation of 1571 approached, both Cheyney's theology and his position as bishop of Gloucester attracted the attention of Archbishop Parker and the other bishops. The Parliament had not approved the Articles of Religion of 1563 . The Convocation of 1571 was to consider amendments before submitting the Articles to Parliament once again, and all the bishops were required to subscribe to them or be excluded from the meeting of Convocation. ${ }^{134}$ When the Convocation convened at St. Paul's on 3 April 1571, Bishop Cheyney was absent, although he was in London. He did not attend either of the first two sessions and then left the city without the archbishop's permission. In the third session of the Convocation, on April 20, Matthew Parker excommunicated him as a result of his "contumacy and manifest contempt in not appearing in our presence."135 Then, on June 15, his chaplain, Anthony Higgens, appeared and explained the bishop's absence by reason of illness. As a result Cheyney was absolved. ${ }^{136}$ All the other bishops had subscribed to the version of the Articles of Religion produced by the

Manning, "Episcopal Authority," 13; Price, "Abuses of Excommunication," 106.

134. Frere, English Church, 162-63.

135. Cardwell, Synodalia, Vol. 2, 529-30.

136. Cardwell, Synodalia, Vol. 2, 530-31. 
Convocation of 1571 on 11 May 1571 . Cheyney never did. ${ }^{137}$

Cheyney's uniquely conservative theology has made him hard to assess.

When he died on 25 April 1579, his successor alleged that he had been a papist. ${ }^{138}$ This charge cannot be substantiated. The Jesuit missionary, Edmund Campion, had failed to persuade him to convert to Catholicism in 1571.

Cheyney had known Campion at Oxford, and when Cheyney was excommunicated, Campion had tried to persuade him "to return to the Roman Church."139 This would seem to indicate that he was not a Catholic then, and there is no evidence that he became one later. He was a very conservative Protestant, however, and, according to Frere, "He was too conscientious to please those who differed from him, and too honest to be silent."140 As a result, his theology alienated him from those around him, including Archbishop Parker. However, he never resigned, nor was he removed from his office.

The information on his administration is extemely scarce. His inability to handle the situation in Bristol, and the ineffectiveness and corruption of his court provide some evidence to support the judgement that he did not

137. G. F. Hodges, Bishop Guest: Articles Twenty-eight and Twenty-nine (London: 1894), 37, cited in C. W. Dugmore, The Mass and the English Reformers (New York: St. Martin's Press, 1958), 225.

138. White, Lives, 177.

139. Strype, Annals, Vol. 2, Part 1, 160-61.

140. Frere, English Church, 162. 
administer his diocese well. However, he probably did attempt to implement the Settlement as he interpreted it. Otherwise, it seems likely that he would have been removed. In fact, he was not removed and, further, there is evidence that Matthew Parker, William Cecil, and some of the other diocesan bishops were willing to compromise to keep him in his bishopric. He was not allowed to resign in 1563. Furthermore, in 1566, Bishop Edmund Guest attempted to negotiate a compromise on the language in the Article XXVIII of the Articles of Religion to appease him. Finally, in 1571 , after initially excommunicating Cheyney, Archbishop Parker agreed to absolve him on the basis of the questionable claim that his absence from the Convocation had been due to illness.

In spite of his attempt to resign and his reluctance to conform, he remained bishop until the end of his life. And, paradoxically, like John Parkhurst, Cheyney's weak administration may have helped produce a broader and more durable Settlement of Religion, as a result of his inability to effectively discipline all religious non-conformists. 


\section{CHAPTER V}

\section{JOHN PARKHURST}

Whereas Richard Cheyney was probably the most conservative bishop appointed by Elizabeth, Parkhurst may have been the closest to the Calvinists - the most zealous reformer among the Elizabethan bishops. Born in about 1512, the son of George Parkhurst of Guildford, Surrey, he entered Magdelan College, Oxford while he was quite young and received his Bachelor of Arts degree in July 1528 . He was admitted as a fellow by Merton College, Oxford in 1529, and gained a reputation as a good Latin scholar. In 1533 he received his Master of Arts degree. ${ }^{141}$

Apparently, Parkhurst accepted Protestantism while he was at Merton College. John Jewel, who became bishop of Salisbury under Elizabeth, came to Merton in July 1535 , and, after initially being assigned to another tutor, was reassigned to Parkhurst. According to John Ayre, the editor of The Works of $\underline{\text { John Jewel, "Parkhurst, who had been previously of Magdalen, was beginning at }}$ this time to be alive to the errors of Romanism; and he accordingly took care to

141. DNB; Register of the University of Oxford, Vol. 1, ed. C. W. Boase (Oxford: Clarendon Press, 1885), 153. 
instill his purer views of divine truth into the mind of his pupil."142 A close friendship developed between the two.

Parkhurst's personal fortunes improved after he wrote Latin verses in honor of King Henry VIII and Queen Catharine Parr, who visited Oxford in 1543. He became chaplain to Catharine Parr in 1547 , and was with her at Sudeley Castle in Gloucestershire just before her death in September 1548. ${ }^{143}$ In 1549 Sir Thomas Seymour granted him the rectorship of Bishop's Cleeve in Gloucestershire. ${ }^{144}$ While there Parkhurst probably became a close friend of the radical Bishop John Hooper of Gloucester. ${ }^{145}$ Also, during his time at Bishop's Cleeve, he developed a close friendship with Peter Martyr, the continental reformer who was a regius professor at Oxford. ${ }^{146}$

With the death of Edward VI and the accession of Mary, Parkhurst fled England and eventually settled in exile in Zurich. However, it was some time before his friends knew where he had gone. Letters from John Jewel to

142. John Ayre, "Biographical Memoir," in The Works of John Jewel, Vol. 4, ed. John Ayre (Cambridge: Cambridge University Press, 1850), vi.

143. R. A. Houlbrooke, "Introduction," in John Parkhurst, The Letter Book of John Parkhurst, ed. Houlbrooke (Norwich: Norfolk Record Society, 1974/5), 22.

144. Houlbrooke, "Introduction," 22; DNB.

145. DNB; White, Lives, 144; Garrett, Exiles, 244.

146. John Strype, Ecclesiastical Memorials, relating Chiefly to Religion, and the Reformation of It, Vol. 2, Part 1 (Oxford: Clarendon Press, 1822), 325. 
Parkhurst illustrate the frantic concern which resulted from the absence of substantive information about Parkhurst's location or condition. On 15 October

1553 Jewel wrote:

O Parkhurst mine, my Parkhurst, what may I imagine you are doing now? That you are dead or alive? That you are in tears, or in the Fleet? Certainly, such has always been the equanimity of your spirit, that I do not doubt that you take all these things, whatever they may be, in good part. ${ }^{147}$

Then on October 22 he wrote:

What shall I now write to you, Parkhurst, or rather, what shall I pass over? I have long been wanting to hear what you are doing, what you have done, in what circumstances you are. . . . [I heard] that you are well, and that you were expecting either myself or a letter from me by the very first opportunity. This was not so agreeable to me, as it is vexing not to know what or whither to write ... For a while ago I tried to find you at Cleeve, at your own house, you were not at home; and, as some told me, you had yielded to the times; as others said, you had altogether one evening left your wife alone, shut up at home, ... . unconcerned about herself, but wretchedly anxious about you. ${ }^{148}$

The dates and route of Parkhurst's flight into exile are not clearly

documented. He could not have arrived in Zurich until sometime after 23 May 1554, because he delivered a letter of that date from Hooper in prison in England to Bullinger in Zurich. He had certainly arrived in Zurich by 13 October 1554, because he signed a letter on that date from Zurich to the exiles

147. Jewel to Parkhurst, from Oxford, 15 October 1553, in Parkhurst, Letter Book, 76-77.

148. Jewel to Parkhurst, from Oxford, 22 October 1553, in Jewel, Works, Vol. 4, 1191; also in Parkhurst, Letter Book, 76. 
in Frankfurt, in which the exiles in Zurich attempted to exert some control over those in Frankfurt. ${ }^{149}$ He lived with Rodolph Gualter while in Zurich, and was in Zurich, when Mary died. ${ }^{150}$

John Parkhurst was one of the first of the exiles to return to England following Mary's death and Elizabeth's accession. On his return he was reinstated as rector of Bishop's Cleeve. In a letter to Josiah Simler, he remarked that he would be content to remain there. He wrote:

Let others have their bishopricks; my Cleeve is enough for me. ... I myself also was to be enrolled among their number; but I implored some of our leading men, and my intimate friends, that my name should be erased from the list ... I have hitherto, by their assistance, kept my neck out of that halter. ${ }^{151}$

Of course, he was not able to keep his "neck out of that halter" for long. Elizabeth confirmed his election to the see of Norwich on 10 July $1560 .{ }^{152}$

Parkhurst was evidently chosen, like others, for his Godly zeal, not his proven administrative ability. ${ }^{153}$ Diarmaid MacCulloch says he was "a kindly and

149. A Brieff Discours off the Troubles begonne at Franckford in Germany Anno Domini 1554 (Zurich (?): C. Froschauer, 1574 (?)), 16.

150. Rodolph Gualter to Lord Francis Russell, from Zurich, 16 January 1559, in Zurich Letters, Vol 2, 10; Christopher Goodman to Martyr, from Geneva, 20 August 1558, in Original Letters, ed. Robinson, 771.

151. Parkhurst to Josiah Simler, from Bishop's Cleeve, 20 December 1559, in Zurich Letters, Vol. 1, 61.

152. Cal. of Patent Rolls, Elizabeth, Vol. 1, 450.

153. Houlbrooke, "Protestant Episcopate," 82. 
scholarly man ... [who] was to prove a hopeless administrator and a poor judge of subordinates." ${ }^{154}$ Not only did he lack administrative skill, he faced significant problems in the diocese of Norwich. The long vacancy in the bishopric created difficulties. The previous bishop, John Hopton, had died eighteen months earlier. ${ }^{155}$ In May 1560 Lord Wentworth, the Lord Lieutenant of Suffolk County, wrote to the archbishop to request that someone be sent immediately to begin to deal with the problems caused by a shortage of qualified clergy and the lack of diocesan leadership. More important, the clergy in the diocesan hierarchy in Norwich did not share Parkhurst's theological views. They were conservatives. ${ }^{156}$ Further, a number of former Marian Privy Councillors were prominent residents of his diocese. ${ }^{157}$ Parkhurst had been given a diocese with an abundance of administrative problems.

Through the first several years of his episcopacy Parkhurst struggled to gain control of his diocese. However, from London and Canterbury it appeared that he had abdicated his authority. In 1568 Matthew Parker organized "a special metropolitan visitation [of the diocese of Norwich] to compensate for his

154. Diarmaid MacCulloch, Suffolk and the Tudors: Politics and Religion in an English County, 1500-1600 (Oxford: Clarendon Press, 1986), 184.

155. Cal. of Patent Rolls, Elizabeth, Vol. 1, 80.

156. MacCulloch, Suffolk and the Tudors, 185.

157. Ann Weikel, "The Marian Council Revisited," in The Mid-Tudor Polity, 71; DNB. 
[Parkhurst's] laxness." ${ }^{158}$ The correspondence between Parkhurst and Archbishop Parker indicates that, in Parker's opinion, problems in the diocese of Norwich centered around a lack of discipline of both the clergy and the laity. Nonconformity occurred with respect to both liturgy and theology. Specific nonconforming behavior among the clergy of the diocese of Norwich included refusal to wear a surplice when presiding at the Eucharist, using loaf bread rather than wafers, the destruction of images and organs in churches, and the preaching of doctrines which were outside the range of acceptable theology of the Church of England.

An anonymous letter, written to Parkhurst and dated 6 March 1573, alleged that Parkhurst had been lax in permitting ministers who had been suspended from their normal duties as a result of their non-conformity, to catechize and prophesy. ${ }^{159}$ This seems to have been consistent with Archbishop Parker's judgement of Parkhurst's administration. In a letter to Cecil, Parker mentioned that Parkhurst "winketh at schismatics and anabaptists, as I am informed." 1160

Parkhurst seems to have been equally lax in disciplining both the most zealous reformers and the most blatant recusants. However, the reasons he

158. Frere, English Church, 153.

159. Anon. to Parkhurst, 6 March 1573, Parkhurst, Letter Book, 231.

160. Parker to Cecil, from Smallbridge, 12 August 1561, in Parker, Correspondence, 149. 
gave for leniency toward reformers tended to be more theological than the reasons he gave for similar treatment of recusants. In dealing with the recusants, he seemed to be motivated mainly by a desire to avoid conflict. In one case, which appears to have been typical, he finally wrote a fairly firm, but still pleading, letter to a Mr. Townsend, who was suspected of being a papist, and whose wife was known to be one. He wrote:

I haue byn often tymes aduertised that you and my ladye your wife do absent your selfes from church and hearing devine service and the receiving of the Sacrament. I haue hoped styll, that my favorable forebearing ... . wold haue moved you to haue confirmed (sic) your selfes. And yet I heare ... that for your owne parte, you come on verye well ... But toching my Ladye, I heare she is wilfullye bente, and little hope as yet of her reformacion, ... . And because I am sharpelye called vppon by some in aucthoritie to se spedie reformacion of such abuses, eyther else to certefye such disobedience, that it may be reformed elsewheare, I haue thought good at this tyme by my friendly lettres to admonysh you and your wife . . . I cold vse many aucthorities and ensamples, but at this tyme I forbere to be tedius. And therfore I eanestlye desire you both [to reform yourselves] ... otherwise this is most assuered, I will not faile to complayne of you both to her Majestie's counsaile ... since you are so freindlye admonished of your faultes, and haue had so longe a tyme to amende. ${ }^{161}$

Parkhurst was really quite a gentle man at heart. He preferred negotiation or persuasion over confrontation. He tried to avoid conflict if at all possible.

The recusancy case that seems to have most upset Archbishop Parker involved a man named Mr. Cotton, who was reported to be living near Norwich.

Parker directed Parkhurst to go and seize both Mr. Cotton's person and his

161. Parkhurst to Mr. Townsend, from Ludham, 12 February 1571, Parkhurst, Letter Book, 119. 
books, but to surprise him because he might flee. Parkhurst found Cotton ill and took his books but did not seize him. As he explained to Parker, Cotton was too sick to travel. Subsequently, Mr. Cotton vanished, and in a series of letters Parker repeatedly asked the whereabouts of Mr. Cotton, who was apparently never apprehended. Parker's exasperation was clear. ${ }^{162}$

Parkhurst also had difficulty controlling the exercises known as prophesyings. He found them valuable, as did many of the other Elizabethan bishops. ${ }^{163} \mathrm{He}$ encouraged and attempted to regulate them. In one case in 1572 he sent letters to three ministers in Bury St. Edmund's, directing them to establish the time and place of the prophesyings, and to determine who should attend and what rules would be followed. ${ }^{164}$ In a letter to his chancellor, dated 7 March 1573, he discussed the problem of suspended clergy participating in prophesyings, and admonished the chancellor to see that participation in prophesyings by suspended clergy was stopped. ${ }^{165}$

162. Parker to Parkhurst, 9 October 1572, 2 November 1572, 2 January 1573, in Parker, Correspondence, 401, 403, 415; Parker to Parkhurst, 19 October 1572, 2 November 1572, in Parkhurst, Letter Book, 140, 147.

163. In 1576, two years after Parkhurst's death, Cox and Cheyney were among the bishops who expressed some degree of approval of prophesyings, in response to Archbishop Grindal's request for their opinions. Patrick Collinson, "Lectures by combination: Structures and Characteristics of Church Life in 17thCentury England," in Godly People, 487.

164. Strype, Annals, Vol. 2, Part 1, 326.

165. Parkhurst to Chancellor of the Diocese, from Ludham, 7 March 1573, Parkhurst, Letter Book, 232. 
Unfortunately, these actions were not sufficient to prevent abuses of the exercises. Apparently the queen heard that the prophesyings were being abused and ordered Archbishop Parker to direct that all prophesyings in the Province of Canterbury be stopped. (She also indicated that she intended to require the same thing for the Province of York. $)^{166}$ As a result, Parker sent a letter to a priest in Norwich on 25 March 1574, directing him to go to Parkhurst and tell him "that the Quene's Majestie wiled me to supresse those vayne prophesienges." Parkhurst responded in a letter dated 2 April 1574 by asking for a clarification of the order and defending the exercises. He wrote:

I wold be glad to be resolued whether you meane therbie the abuse of some vaine speches vsed in some of those conferences, or ells generally thole order of thos exercyses, which surely haue and do daily bring singular benefitte to the Church of God aswell in the clergie as the layitie, and is aright necessary exercise to be contynued. ${ }^{167}$

He also wrote to Edmund Grindal and others in London, seeking advice about how to respond to the order. Grindal did not respond immediately, but others did. Edwin Sandys, Sir Thomas Smith, Sir Francis Knollys, and Sir Walter Mildmay wrote to Parkhurst on May 6th, and, after lauding prophesyings as valuable and acknowledging their contribution to the education of clergy and laity in such towns as Holt in Norfolk, they went on to say,

166. Queen Elizabeth to Parker, 25 January 1564, in Parker, Correspondence, 223-27; Strype, Annals, Vol. 2, Part 1, 477.

167. Parkhurst to Dr. Gardyner, from Ludham, 3 April 1574, Parkhurst, Letter Book, 235-36. 
Theis (sic) are to require your Lordship that so long as the truth is godly and reuerently vttered in this prophesieng, and that no sedicious heretical or schismaticall doctrine, tending to the disturbance of the peace of the church, can be proved to be taught or maynteyned in the same, that so good an helpe and meane to further true religion may not be hindered or stayed, but may procede and go forward, to Gode's glory and the edefieng of the people. ${ }^{168}$

Some of the authors of this letter were members of the Privy Council. ${ }^{169}$ Now Parkhurst had received conflicting directives from two different recognized authorities: the Privy Council and the archbishop of Canterbury. Parker heard of the letter from Sandys and wrote to Parkhurst on May 17, asking Parkhurst to "signifie vnto me what there (sic) warrante is." He went on to scold Parkhurst for having even requested further clarification of the order, saying, finally, "It is pitye we shold showe any vanitye in our obedience." Ultimately, on 7 June 1574, Parkhurst gave in and ordered the prophesyings suspended in the diocese of Norwich. He then discovered that his was the only diocese where the order was actually enforced. ${ }^{170}$

Parkhurst never seemed to realize what he was doing wrong administratively. In one communication in response to Articles of Visitation he

168. Edwin Sandys et al. to Parkhurst, from London, 6 May 1574, Parkhurst, Letter Book, 242.

169. Smith, Knollys and Mildmay were all members of the Privy Council at that time. Michael B. Pulman, The Elizabethan Privy Council in the Fifteen Seventies (Berkeley, California: University of California Press, 1971), 17-18.

170. Freake, bishop of Rochester, to Parkhurst, from the court, 13 June 1574, in Parkhurst, Letter Book, 246. 
carefully described the organizational structure of the diocesan hierarchy. ${ }^{171}$ In another response he excused himself from a particular action because it was not customary in the diocese of Norwich, continuing, "and bycause it can not be done without some tracte of tyme, and assemble of people to that effort, I most humblie beseche your honors to lett me undersstande your ffurther (sic) pleasures in that behalf."172 This communication is typical. He repeatedly made excuses for himself, or attempted to explain away his apparent mismanagement. He seemed either unwilling or unable to take the steps necessary to ensure that his diocese was managed adequately. He had the right form of administration, but there was no substance. He seemed to lack the knowledge and the energy to manage the diocesan organization to meet the demands for tighter discipline and better stewardship of his diocese.

When Parkhurst had first returned from exile, he had been very hopeful for the progress of the Reformation in England, but he felt there was still much to do. On 21 May 1559 he told Conrad Gesner, "The pope is again cast out of England. The pseudo-bishops ... . are now abhorred both by God and man, and never creep out into public." He wrote in August 1560 that "many pious persons are quite satisfied; as for myself, a few things still remain unsatisfactory, but I hope for an improvement." He took steps in his diocese to improve

171. Parkhurst, "Report on Diocesan Organizational Structure," British Library Lansdowne Collection 6, 60 (fols. 148-50).

172. Parkhurst, "On the Jurisdiction and Management of his Diocese," July, 1563, British Library Lansdowne Collection 6, 60 (fol. 141). 
religion by directing "In towns where there were several parishes the common prayers were to be finished in each church by nine o'clock on Sunday morning, in order that all might resort to the sermon whenever one was preached."173 Two years later, as he awaited the beginning of the Convocation of 1563 , he was still hoping for other improvements in English piety. ${ }^{174}$

Several of the most difficult issues of the day involved proposed liturgical changes. However, Parkhurst did not consider these matters to be essential to improving Christian piety in England. Many of the former Marian exiles, including Parkhurst, had come to appreciate the simpler form of worship they found on the continent. Parkhurst held as his ideal the form of worship he had experienced in Zurich. He described it as "a perfect model." However, he wrote to Gualter that he was willing to accept both the ceremonies and vestments of the Elizabethan Church of England, believing in particular that the vestments were adiaphora, or items indifferent to the spread of the Gospel. In fact, he indicated that he did not approve of the decision by some to "abandon the cures of souls entrusted to them," rather than wear the prescribed vestments. ${ }^{175}$

173. Frere, English Church, 62.

174. Parkhurst to Bullinger, from Ludham, 28 April 1562, in Zurich Letters, Vol. 1, 108.

175. Parkhurst to Gualter, from Ludham, c.1573, in Parkhurst, Letter Book, 81. 
He felt somewhat more strongly about the presences of images in the church, however. He seems to have been encouraged by the actions of one individual early in 1563 . He wrote to Bullinger:

Lo! good news was brought to me, namely, that the crucifix and candlesticks in the queen's chapel are broken in pieces, and, as some one has brought word, reduced to ashes. A good riddance of such a cross as that! $!^{176}$

Of course the images were soon replaced, but in April 1563 Parkhurst reported to Bullinger that the candles were no longer being lit. He was clearly pleased by this development. ${ }^{177}$

In January 1564 he had an opportunity to demonstrate his preference with regard to images. He described the event to Josiah Simler:

The wife of the duke of Norfolk died in childbed on the 10th of January, and was buried at Norwich on the 24th of the same month. I preached her funeral sermon. There were no ceremonies at the funeral, wax candles or torches. Except the sun nothing shone, which sadly annoyed the papists. Nothing of the kind has been ever seen in England, especially at the funeral of a peer or peeress. ${ }^{178}$

Unfortunately, Parkhurst's participation at this level in his diocese was a rare occurrence. He seldom left his home in Ludham to become actively involved in the affairs of his diocese. He assumed that his commissioners were taking care

176. Parkhurst to Conrad Gesner, 21 May 1559; Parkhurst to Bullinger, 23 August 1560, 28 April 1562, 20 August 1562, in Zurich Letters, Vol. 1, 31, 91, $108,122$.

177. Parkhurst to Bullinger, from Ludham, Zurich Letters, Vol. 1, 129.

178. Parkhurst to Josiah Simler, 17 February 1564, from Ludham, in Zurich Letters, Vol. 1, 137. 
of those matters.

Through Parkhurst's actions it is possible to deduce his theology. He clearly preferred the liturgy of Zurich-a simple, scripturally focussed form. This indicates that he saw worship as a way for people to come to know God, and probably believed in salvation by faith alone, for simplified worship was one of the results of the belief in justification by faith alone. Also, worship services were no longer seen as "good works" necessary for salvation. His acceptance of a bishopric demonstrated his support of the episcopal form of church government. His opposition to images in churches indicates a desire for simplicity. However, it also indicates an abhorrence of liturgical embellishments which might encourage superstitions, such as those attributed to papist Eucharistic theology by the reformers. These included the Eucharistic theory of transubstantiation, but also the concept of the Mass as a sacrifice and the belief that participation in the Mass was necessary for salvation. His position on images, combined with his preference for simple liturgical forms, also make it likely that he viewed the Eucharist as a memorial, but the evidence is inconclusive.

Parkhurst died at Ludham on 2 February $1575 .{ }^{179}$ His letters portray an unhappy and embattled man. He certainly had known that his episcopal administration had been found wanting, but he had never offered to resign his

179. White, Lives, 152. 
bishopric. Like Richard Cheyney and several of the other early Elizabethan bishops, his lack of administrative skill clearly had hindered his ability to implement the Elizabethan Settlement of Religion in Norwich, as originally defined. However, he did still work for its implementation and, in his own way, may have strengthened it. His ineffective administration, combined with the popular resistance to change on the one hand and the desire for more radical change on the other, had a broadening effect on the Settlement as implemented in the diocese of Norwich. 


\section{CHAPTER VI}

\section{RICHARD COX}

Richard Cox was one of the first Elizabethan bishops chosen. As a priest he had been involved in the English Reformation beginning in 1534, when he subscribed to the bishops' statement refuting papal supremacy. ${ }^{180}$ At the beginning of Elizabeth's reign he was one of the most highly respected members of the clergy, probably because of his close relationship with Thomas Cranmer and the other leaders of the Edwardian Reformation. He was also respected as a result of his role in settling the conflict among the exiles in Frankfurt during Mary's reign. He was initially chosen to be bishop of Norwich after Elizabeth's accession. ${ }^{181}$ However, the see of Ely became vacant, as a result of the deposition of Bishop Thirlby, before Cox was consecrated Bishop of Norwich. Elizabeth then nominated him for Ely, and Parkhurst for Norwich.

Born in about 1500 at Whaddon in Buckinghamshire, Cox may have received his early education at a Benedictine priory near his home. He then went to Eton, and from there proceeded to Cambridge, where he entered King's

180. Foxe, Acts and Monuments, Vol. 5, 87-89.

181. Henry Machyn, The Diary of Henry Machyn, from A.D. 1550 to A.D. 1563, ed. J. G. Nichols (London: J. B. Nichols and Sons, 1848), 201. 
College in 1519. He received his Bachelor of Arts degree in 1524. A short time later he was one of several scholars to be invited by Cardinal Wolsey to become a member of the cardinal's new college at Oxford. ${ }^{182}$

Wolsey invited Cox to Oxford to help stop the spread of Lutheranism there. Instead, however, he seems to have been converted to Protestantism, although he may have been a Protestant before he left Cambridge. One historian has reported that, having been found in possession of Tyndale's Bible and other Protestant books, Cox and several others were locked in a cellar where salt fish were kept. They were then allegedly left there for five months, during which time four of them died. I could find no evidence to support this story. However, Strype reports that those who were influenced by the Protestant books at Oxford included Frith, Drum, and Cox, as well as others. ${ }^{183}$ In any case, Cox's stay in Oxford was rather short. He soon left to become headmaster of Eton. ${ }^{184} \mathrm{He}$ received his Doctor of Divinity degree from Cambridge in $1537^{185}$

182. DNB; Cooper, Ant. Cant., Vol. 1, 437. Wolsey's college was initially called Cardinal College, but later became Christ Church College. Anthony A. Wood, Athenae Oxonienses, Vol. 1 (London: F. C. and J. Rivington, 1813), col. 465 .

183. George F. Bridges, The Oxford Reformers and English Church Principles, ed. W. G. Bridges (London: Elliot Stock, 1908), 248-49; Strype, Memorials, Vol. 1, Part 1, 569.

184. White, Lives, 79.

185. DNB; Cooper, Ath. Cant., Vol. 1, 437. 
While he was at Eton, Cox came to prominence. As noted above, he subscribed to the Bishop's statement renouncing the papacy in 1534 . In 1540 he was chaplain to King Henry VIII and voted for the annulment of the king's marriage to Anne of Cleves in the Convocation of $1540 .{ }^{186}$ He attended the Convocation of 1541 as archdeacon of Ely and preached the sermon at the opening Mass. ${ }^{187}$ A number of lucrative preferments followed, including his appointment as dean of the cathedral of Oseney. ${ }^{188}$ However, his key appointment during Henry's reign was as tutor to Prince Edward. He was appointed to that position sometime before 1543, and John Cheke joined him in 1544. ${ }^{189}$ In that position they were able to educate the future king as a

186. White, Lives, 79.

187. Strype, Memorials, Vol. 1, Part 1, 573.

188. Christ Church, Oxford later replaced Oseney as the cathedral for the diocese and Cox became dean of Christ Church. White, Lives, 79-80; Cooper, Ant. Cant., Vol. 1, 438.

189. W. K. Jordan, Edward VI: The Young King, (London: George Allen and Unwin, 1968), 40; Hester W. Chapman, The Last Tudor King: A Study of Edward VI, (New York: Macmillan Co., 1958), 53. 
Protestant. ${ }^{190}$ On 7 July 1544, Cox also became almoner to Prince Edward. ${ }^{191}$

However, Cox remained as Henry VIII's chaplain at least as late as $1546 .{ }^{192}$ In fact, it appears that he held a number of his preferments simultaneously.

Cox's career continued to be associated with the court after the accession of Edward VI. On 16 March 1547 Cox was named almoner to the king, which was effectively a continuation of his previous position. ${ }^{193}$ On May 21 of the same year he was elected as chancellor of Oxford University, which enabled him to offer hospitality and support to continental divines, such as Peter Martyr, Stumphius, and John ab Ulmis. ${ }^{194}$ Also that year, as dean of Christ Church, he was named to a commission which was to prepare a "uniform order of

190. Cox was apparently responsible for educating Edward concerning manners, philosophy and divinity. Cheke was responsible for mathematics and languages. Burnet, Reformation, Vol. 2, 2. There is evidence that Cox was also tutor to Lady Jane Grey and the Princess Elizabeth. David J. Keep, "Theology as a Basis for Policy in the Elizabethan Church," in The Materials, Sources and Methods of Ecclesiastical History, ed. Derek Baker (Oxford: Basil Blackwell, 1975), 268.

191. Cooper, Ath. Cant., Vol. 1, 438.

192. Strype, Memorials, Vol. 2, Part 1, 16.

193. According to Cooper, he was named to the Privy Council and appointed one of the Masters of Requests a short time later. Cooper, Ath. Cant., Vol. 1, 438. I can find no evidence to support these claims, although I did find that a Dr. John Cox was named Master of the Court of Requests. APC, Vol 2, passim; D.E. Hoak, The King's Council in the Reign of Edward VI (Cambridge: Cambridge University Press, 1976), 269.

194. Also, in 1549, he was apparently one of a group of visitors who confiscated and destroyed papist books and manuscripts belonging to the various colleges of the Oxford University. Cooper, Ath. Cant., Vol. 1, 438; DNB. 
communion, according to the rules of Scripture, and the use of the primitive church."'195

The following year his involvement in liturgical matters continued when that same group of bishops and other divines was reconstituted as a commission to prepare or at least approve the first Book of Common Prayer. ${ }^{196}$ Then, on 6 October 1549, Cox was named as one of thirty-two members of a commission to reform the ecclesiastical laws of the Church of England, which had not been revised since the split with Rome. A month later that commission was reduced to eight members, and Cox was one of those eight. ${ }^{197}$

By 27 March 1550, Cox was no longer the king's tutor, although he remained as his almoner. ${ }^{198}$ Also, in October of the preceding year he had been named dean of Westminster. Throughout the remainder of Edward's reign Cox's name kept appearing in lists of commissioners to carry out various tasks,

195. Zurich Letters, Vol. 1, 234n.

196. There is every indication that this commission could not actually have drafted the Prayer Book. They completed their work in just three weeks. Probably they reviewed a draft, prepared by Cranmer and a few others, possibly including Cox. Cuming, Anglican Liturgy, 46; Burnet, Reformation, Vol. 2, 97. 98; Zurich Letters, Vol. 1, 235n.

197. The eight members of the smaller commission were Thomas Cranmer, the bishop of Ely, Richard Cox, Peter Martyr, Dr. Taylor of Hadley, Dr. May, John Lucas and Richard Goodrich. APC, Vol. 3, 410; Cooper, Ath. Cant., Vol. 1, 439.

198. Hooper to Bullinger, from London, 27 March 1550, in Original Letters, ed. Robinson, 82. 
typically in the following language:

A commission to Thomas Archbishop of Canterbury, . . . Richard Cocks, . . . or to any thirty-one, thirty, . . f five, four or three of them; whereof the Archbishop of Canterbury, the Bishop of Norwich, the Bishop of Rochester, .. . [or] Richard Cox . . . be one. ${ }^{199}$

Clearly, Cox was highly respected as a religious leader at that time. He was also still connected to the court, although he was not always on the winning side. On 22 January 1552 Cox stood on the scaffold as Somerset gave his farewell speech. Then Cox placed a prayer he had written in Somerset's hands. Somerset is reported to have read it on his knees, and then disrobed in preparation for his execution. ${ }^{200}$

Edward's death again placed Cox on the wrong side. He had been an outspoken leader of the Edwardian Reformation. Both his theological opinions and his involvement in the liturgical changes of that reign seem to have been well-known. Also, he was a married priest, which would have made him particularly unpopular with Mary. Finally, and of most immediate importance, he was implicated in the attempt to place his former pupil, Lady Jane Grey, on the throne. As a result of that alleged complicity he was arrested. ${ }^{201} \mathrm{He}$ was deprived of all his preferments and on 5 August 1553 was imprisoned in the

199. Strype, Memorials, Vol. 2, Part 1, 200.

200. Burnet, Reformation, Vol. 2, 296.

201. John Burcher to Bullinger, from Strassburg, 16 August 1553, in Original Letters, ed. Robinson, 684. 
Marshalsea on a charge of treason..$^{202}$ He was released on August 19 and placed under house-arrest. Nine months later he and Edwin Sandys escaped to the continent. They apparently landed in Antwerp and then proceeded to Strassburg although there is no record of Cox ever being in Strassburg. ${ }^{203}$

Cox lived in exile on the continent from the summer of 1554 until the winter of $1558 / 9$. However, the story of his life during those years focuses on the period from 13 March 1555, when he arrived in Frankfurt, through late autumn of that same year, when he left. ${ }^{204}$

The English religious exiles living in each city on the continent were faced with the problem of deciding what form of worship they would use while living in exile. As noted above, the two main choices were the second Prayer Book of Edward VI, perhaps with minor modifications, and an English-language worship service, based on Calvin's Geneva Order. In order to decide on a form of worship the exiles in each city had to agree among themselves, and their choice had to be acceptable to the local magistrates. In fact, the local magistrates had quite a bit of control over the congregations in exile. As the experience of the congregation in Frankfurt illustrates, the magistrates controlled not only the form of worship adopted by the congregation, but also the leadership and membership of the congregation.

202. Machyn, Diary, 39.

203. Garrett, Exiles, 134.

204. Garrett, Exiles, 134-35. 
The English exiles arrived at Frankfurt in June 1554 and obtained permission from the magistrates to use the French Protestant Church for worship. In their negotiations with the magistrates they agreed to call "two or three 'grave, godlie, and learned ministers, of like [or equal] authoritie, as is accustomed in the best Reformed churches." They also agreed to use a form of worship which was as similar as possible to that of the French Church, which, in turn, was similar to the forms used in Geneva. ${ }^{205}$

The earliest exiles arrived in Frankfurt on June 27. The leaders of that group were Edmund Sutton, William Williams, William Whittingham, and Thomas Wood. They approached the magistrates and asked "for a place or churche, wherin they and all their country men might have God's Worde truly preached, and the Sacraments sincerely ministred in their naturall tonge." With the understanding that their liturgy was to conform closely to that of the French Church, they then began the process of determining their order of service.

At length the Englishe Order was perused, and this, by generall consent, was concluded, that the Answeringe alowde after the minister shulde not be used; the Letanye, Surplice, and many other thinges also omitted, for that in those Reformed churches suche thinges woulde seeme more then strange. It was farther agreed uppon, that the minister (in place of the Englishe Confession) shulde use an other, bothe of more effecte, and also framed accordinge to the state and time. And the same ended, the people to singe a psalme in meetre, in a plaine tune, ... that done, the minister to praye for the assistance of God's Holie Spirite, and so to proceade to the sermon. After the sermon, a generall praier for all estates, and for oure

205. "A Narrative of the Proceedings and Troubles of the English Congregation at Frankfurt on the Maine," in The Works of John Knox, Vol. 4, ed. David Laing (Edinburgh: James Thin, 1895), 3. 
countrie of Englande, was also devised; at th'ende of whiche praier was joined the Lord's Praier, and a rehersall of th'articles of oure belief; which ended, the people to singe one other psalme, as afore. Then the minister pronouncinge this blessinge, 'The peace of God,' $\& c .$, or some other of like effecte, the people to departe.

And as touchinge the ministration of the Sacraments, sundrie things were also, by common consente, omitted as superstitious and superfluous. ${ }^{206}$

Key changes in this liturgy, from that contained in the second Book of Common Prayer, included the omission of congregational responses, the litany, vestments, and a change in the style of psalm-singing. In addition, the description of the 1552 Prayer Book, sent to Calvin by this group, indicates that all references to saints' days were omitted, the Gloria was omitted, and the Prayer for the Church was probably simplified. ${ }^{207}$

While the congregation was attempting to call ministers and determine the form of worship they would use, leaders among the English exiles in other cities were busy nominating prominent clerics to go to Frankfurt to lead the congregation there. In August 1554 Edmund Grindal, who was in Strassburg, wrote to John Scory, a former bishop currently living in Emden, to persuade him to go to Frankfurt and become superintendent of the congregation there. Scory wrote to the exiles in Frankfurt, but they believed they had the right to choose their own ministers. They had previously written to John Knox in Geneva,

206. Troubles at Franckford, 6-7.

207. Troubles at Franckford, 30-32. 
James Haddon in Strassburg and Thomas Lever in Zurich, asking them to be their ministers. ${ }^{208}$

Knox promptly accepted the call to go to Frankfurt, and, after initially not replying, Lever accepted, as well. Haddon declined. ${ }^{209}$ However, this was not the end of the attempt by the exile leaders in other cities to influence the proceedings in Frankfurt. A number of additional letters followed, as well as visits to Frankfurt by prominent exiles, including Grindal. Then, on 13 March 1555, Richard Cox and a group of exiles arrived. ${ }^{210}$

As noted above, each of the exiled congregations had to decide on the liturgy to be used. Those in Emden, Zurich, and Strassburg had chosen forms of worship which were very close to the second Prayer Book. Richard Cox's presence in Frankfurt signalled the fact that the exiles in those other cities probably considered Frankfurt's conformity to the second Prayer Book to be important to the future of the English Church in exile. It is likely that key individuals from those congregations urged Cox to go there.

Richard Cox had probably helped write both Edwardian Prayer Books.

He had stature among the exiles as a liturgist. He believed the Prayer Book of

208. Troubles at Franckford, 11-13; Collinson, Grindal, 73-75.

209. Troubles at Franckford, 16, 19, 28.

210. Troubles at Franckford, 38. It is interesting to note that in his "Narrative," Knox only mentions Richard Cox in passing, and focuses on Lever as the leader of the opposition. Jasper Ridley, John Knox (Oxford: Clarendon Press, 1968), 199. 
1552 represented the right form of worship. He also believed that the rejection of that book would send a message of non-support to its authors, who were about to die at the stake in England for their beliefs. Knox, on the other hand, had opposed the second Prayer Book, especially the provision requiring that people kneel to receive communion. His sermon before the king and the Privy Council in September 1552 had prompted the addition of the "Black Rubric" just before that book was published. ${ }^{211}$

Now Cox, representing the authors of the second Prayer Book, and Knox, who had opposed it before the king, were both in Frankfurt. A series of confrontations in meetings and in worship services, plus the timely presentation to the magistrates of information harmful to Knox, followed. According to most of the accounts of these events, the leader of this effort in support of the Prayer Book was clearly Cox. Only Knox's account seems to indicate otherwise. He does not mention Cox as the leader, but rather focuses on Lever. The final result was that Knox and his supporters left Frankfurt. Those who remained adopted a liturgy much closer to the second Prayer Book than that adopted by

211. That rubric however, rather than prohibiting kneeling, as Knox had hoped, required it. The rubric then explained that the act of kneeling did not represent adoration of the Sacrament, but only its importance. Cuming, Anglican Liturgy, 85; John Utenhovius to Bullinger, from London, 12 October 1552, in Original Letters, ed. Robinson, 591; Fred H. Cate, "Thomas Cranmer's Eucharistic Doctrine and The Prayer Books of Edward VI," Historical Magazine of the Protestant Episcopal Church, 55 (June, 1986): 109; Prayer Books, 393. 
the congregation before Cox's arrival. ${ }^{212}$

According to most accounts, Cox had arrived in Frankfurt after the question of liturgy had been resolved to the satisfaction of all those then in Frankfurt. After he and his followers were finished, however, they had replaced the liturgy. They had also replaced many of the original members of the congregation. Most of those who had supported the original decision left soon after Knox had left.

It seems to have been very important to Cox to preserve the use of a form of worship that was similar to the second Prayer Book. His perception of the events in Frankfurt were clearly at variance with the perceptions of those who prepared most of the complete narratives describing those events. Cox wrote to Calvin on 5 April 1555,

When the magistrates lately gave us permission to adopt the rites of our native country, we freely relinquished all those ceremonies which were regarded by our brethren as offensive and inconvenient. ... We retain however the remainder of the form of prayer and of the administration of the sacraments, which is prescribed in our book, and this with the consent of almost the whole church, the judgement of which matters of this sort we did not think should be disregarded ... the greatest care being taken that every one should be at perfect liberty to vote as he pleased. ${ }^{213}$

The liturgy Cox and his followers adopted in Frankfurt was close to the

212. Troubles at Franckford, 38-47, 51, 55-59; John Knox, "A Narrative by Knox of the Proceedings of the English Congregation at Frankfurt, in March 1555" in Knox, Works, Vol. 4, 41-49.

213. Cox to Calvin, from Frankfort, 5 April 1555, in Original Letters, ed. Robinson, 753-54. 
Prayer Book but not identical. The preface indicates that they chose to omit "in respect of time, place, and such circumstances, certain rites and ceremonies appointed in the said book, as things of their own nature indifferent." Specifically, they seem to have omitted almost all rubrics and simplified the services. Optional psalms after the lesson were eliminated from Morning Prayer. Both Morning and Evening prayer now had only one lesson. In the Communion Service the Prayer for the Whole State of Christ's Church was moved earlier in the service, before the Creed. The Sanctus and Sursum Corda were apparently eliminated. In the service of baptism the instructions, which previously had been given to the godparents, were now given to the father of the newly baptized. ${ }^{214}$

Once matters in Frankfurt had been resolved to Cox's satisfaction, he left that city and probably returned to Strassburg, although there is no clear evidence to that effect. He was in Worms when Mary died; he promptly returned to England. ${ }^{215}$

Cox was one of the former exiles who preached before Queen Elizabeth several times during the first few months of her reign. He was, after all, a prominent Edwardian divine who was well known to Cecil. Most notably, he preached the sermon at the opening of Elizabeth's first Parliament on 25

214. Both Sprott and Garrett believe this to be Cox's "Liturgy of Frankfort" rather than Knox's "Liturgy of Compromise." "The Order of Common Prayer," in The Liturgy of Compromise, ed. George W. Sprott, (London: William Blackwood and Sons, 1905), 232-39; Prayer Books, 347-403, passim; Garrett, Exiles, 135.

215. Cooper, Ath. Cant., Vol. 1, 441. 
January 1559. The liturgy of the opening service and the content of Cox's sermon were reported with obvious distaste by the Venetian ambassador, Il Schifanoya. He mentioned that the Mass had been said earlier "without elevating the Sacrament," and that, when the queen's procession arrived at Westminster Abbey for the formal opening service, she dismissed the monks with their lighted torches who had been waiting to accompany her into the abbey. He then said,

Dr. Cox, a married priest, who has hitherto been beyond the sea, ascended the pulpit and preached the sermon, in which, after saying many things freely against the monks, proving by his arguments that they ought to be persecuted and punished by her majesty, as they were impious for having caused the burning of so many poor innocents under pretext of heresy, on which he expatiated greatly; he then commenced praising her Majesty, ... exhorting her to destroy the images of the saints, the churches, the monasteries, and all other things dedicated to divine worship; proving by his own arguments, that it is very great impiety and idolatiy to endure them. ${ }^{216}$

Cox expanded on the theme of eliminating images from churches over the next several months. In 1559 he joined with Matthew Parker and others to write a letter to Elizabeth that articulated the theological "Reasons Against Images in Churches." They asserted that images in churches were against the second commandment; they were not supported by Scripture; they were not edifying; they were dangerous in that they could lead the weak and superstitious astray; they were hurtful to the greatest number of people; and they distracted the mind from prayer. The authors then went on to support their assertions 
with citations from the writings of the early church fathers, from church councils, and from church histories. ${ }^{217}$

In late 1559 or early 1560 Cox wrote a personal letter to the queen respectfully declining to preside at the Eucharist in her chapel, "the lights [candles] and cross remaining." In that letter he cited the same reasons as in the letter above to support his position. ${ }^{218}$

Following these strong stands in opposition to images in churches, it is somewhat surprising that only a few weeks later, on 5 February 1560 , Cox joined Parker in supporting the use of such images in a disputation. They were opposed by John Jewel and Edmund Grindal, and Jewel believed that, as a result of that disputation, he, Jewel, would not be a bishop for much longer. In a letter to Peter Martyr, he said,

I will write you more at length when the disputation is over; for the controversy is as yet undecided; yet, as far as I can conjecture, I shall not again write to you as a bishop. For matters are come to pass, that either the crosses of silver and tine, which we have every where broken in pieces, must be restored, or our bishopricks relinquished. ${ }^{219}$

As matters developed, neither of Jewel's predictions came true. The disputation was inconclusive. The only cross that remained was in the queen's chapel. The

217. Parker, Correspondence, 79-93.

218. Strype, Annals, Vol. 1, Part 2, 500-501; Frere, English Church, 53-54.

219. Jewel to Martyr, from London, 4 February 1560, in Zurich Letters, Vol. 1, 67-68. 
others were not restored. ${ }^{220}$ John Jewel remained bishop of Salisbury until his death in $1571 .^{221}$ More importantly, historians have apparently failed to discover an explanation for the change in Cox's position. He had risked his career by refusing to officiate when the images were present, and then in the disputation he defended their presence.

During the early years of Elizabeth's reign, the issue of images was the only major theological or liturgical issue on which Cox asserted a strong belief or opinion. Much later, in 1577, he supported prophesyings when Elizabeth was attacking Archbishop Grindal for his support of those exercises. At that time he wrote to Cecil,

When the great ignorance, idleness, and lewddness of the great number of poor and blind priests in the clergy, shall be deeply weighed and considered of, it will be thought most necessary to call them, and to drive them, to some travel and exercise of God's holy word: whereby they may be the better able to discharge their bounden duty towards their flock. I trust I shall not need either with words or reasons to move your righteous heart to mitigate her majesties displeasure and indignation against her archbishop. ${ }^{222}$

Elizabeth confirmed Richard Cox's election as bishop of Ely on 18

December $1559 .{ }^{223}$ During the first year of Elizabeth's reign, in addition to preaching and objecting to images in churches, he had again served on a

220. Haugaard, Elizabeth and the English Reformation, 196.

221. DNB.

222. Strype, Annals, Vol. 2, Part 2, 611.

223. Cal. of Patent Rolls, Elizabeth, Vol. 1, 450. 
commission to revise the Prayer Book and on the commission which administered the Oath of Supremacy to the clergy. ${ }^{224}$

As a bishop he administered his diocese conscientiously. At one point Hooper had advised other church leaders that the only way to effectively administer a diocese was to delegate part of the responsibility to regional representatives, such as archdeacons. Cox is apparently the only Elizabethan bishop who effectively followed Hooper's advice. ${ }^{225}$ Cox was able to maintain discipline among both the clergy and the laity in his diocese. He was also able to give attention to certain problems which he judged warranted his personal involvement.

One such problem, or set of problems, was the lack of discipline exhibited in St. John's College, Cambridge. Members of the college contended that they needed new statutes on the selection of a Master. Cox took a detailed interest in this issue. He wrote:

Sir, accordinge to yor request and upon thesame accordinge to the request also of themost parte of the ffellowes of St. John's, I have trawayled to pacifie the contention lately risen in the howse. And by conference with bothe parties I fynde that their ellection is vtterly frustrate, bothe because the mastershipe is not yet voyed neyther by forfayture nor by resignation and also because they have made a certayne ellection contrarye to the forme, and ordre of their statute. ... I willed them in the meane season to be quyet, and when the rome of the mastershipe shalbe clerely voyed than (sic) to proceade

224. Cooper, Ath. Cant., Vol. 1, 440.

225. Collinson, "Episcopacy and Reform," 171-72. 
to a newe ellection, accordinge to the tenour of their statutes. ${ }^{226}$ He was involved at the same level of detail in dealing with the dispute over vestments. Members of St. John's were refusing to wear surplices for services. In a letter, dated 13 December 1564, Cecil asked Cox to deal with the matter, asserting "That in this matter nothing was more requisite than speed and severity."227 Cox wrote to Peterhouse College in 1565, "That he hoped, after this unseemly storm in the university, there would follow a godly (sic) calm."228 $\mathrm{He}$ had dealt with these problems in a way that Parkhurst would never have considered.

Cox took a similarly active role in dealing with members of the sect known as the Family of Love, which was a branch of Anabaptism. ${ }^{229} \mathrm{He}$ personally examined a number of suspected members, most notably at Wysbytch in October 1580. The examination in that instance was quite detailed. It began with a brief homily concerning false prophets and strange gods. Then each of those accused was examined individually. The account of the examination of John Bourne says that he "was in examination two dayes togeather. The first daye he was very obstynate and wilfull, and would confesse nothing, no, not

226. Cox to Cecil, from Cambridge, August 1563, British Library Lansdowne Collection 6, 67 (fol. 164).

227. Strype, Annals, Vol. 1, Part 2, 157-58.

228. Strype, Annals, Vol. 1, Part 2, 159.

229. Dickens, English Reformation, 238. 
upon his othe, but denyed those things." This apparently continued until the evening of the second day, when he finally agreed to answer the questions. But even then, he either denied each charge or responded without actually answering the question. ${ }^{230}$ This examination was obviously a long and arduous process, especially for a man of Cox's age. However, it illustrates his willingness to devote the time and energy required to adequately administer his diocese.

Cox died on 22 July 1581 . He was approximately 81 years of age. ${ }^{231} \mathrm{He}$ had served as a priest for approximately fifty years, through the time of the greatest religious upheaval in the history of England. He had been venerated and recognized as a spiritual and ecclesiastical leader.

His theology and his Erastianism had guided his actions through most of his career. His Erastianism led him to support the religious policies of his sovereigns with few exceptions. He seems to have fully supported Henry and Edward. Under Elizabeth he did object to the use of images and to her position on clerical marriage. Otherwise, he seems to have supported Elizabeth as well. In fact, his change of heart concerning images may have been due to his Erastianism. His theology had been developed early in his career, and his beliefs are recorded in his responses to two sets of questions which were asked of the bishops and a group of divines.

230. Richard Cox, "Examination of some of the Family of Love at Wysbytch, Oct. 1580," in Gonville and Caius College MS 53/30, fols. 126v-29r.

231. DNB. 
The first set of questions was posed in 1540 and concerned the nature of the sacraments. ${ }^{232}$ Cox said that he could not find a scriptural definition of a sacrament, and that, further, none of the ancient church fathers had defined it. However, he asserted that Scripture referred to various sacraments, as did the ancient church fathers. With respect to the Catholic assertion that there were seven sacraments, he said,

This word Sacrament is not, nor ought not to be attributed to these seven only. Those that we call seven Sacraments, be found in old Authors, although some of them be seldom found called by this name Sacrament.

He further asserted that there was no doctrine prescribing seven sacraments. However, a number of those things which were labelled as sacraments were referenced in Scripture, specifically, baptism, the Eucharist, penance, matrimony, clerical orders, and unction of the sick. He indicated that he could find no Scriptural reference to the use of oil of chrism in the baptismal rite. Further, he said that the Apostles had the right to exhort and induce men to become priests, and that bishops were made from priests. In this set of questions, he then went on to discuss the details of who had the right to ordain priests in various circumstances. $^{233}$ The main focus of his responses seems to have been to narrow the definition and nature of sacraments, as other reformers had done, and to support the episcopal form of church government.

232. DNB.

233. Burnet, Reformation, Vol. 4, 114-30. 
In a second set of questions, asked in 1548, Cox described his theory of the Eucharist. ${ }^{234}$

The Sacrament of the Altar was instituted to be received of every Man for himself, and not for one another. ... The receiving of the said Sacrament doth avail and profit the Receiver only, and none other, but by occasion to do the like. ... The Oblation of the Sacrifice of Christ in the Mass, is the Prayer, the Thanksgiving, and the remembrance of Christ's Passion and Death. ... The Mass, by Christ's Institution, consisteth in Thanksgiving of the Father, in distributing of the Body and Blood of Christ to the Congregation, to have the Death and Passion of Christ in remembrance, and in the end to laud and praise God. ... I I think it not convenient that the said custom [of the priest communing alone] should continue, if by any godly Mean the People might be brought to receive the Sacrament with the Priest. . . . Masses to be said for satisfaction of Sin ... is an Abuse ... In the Mass-time, it were convenient to have some Doctrines after the Example of the Primitive Church, that at the Blessed Communion the people might be edified. ${ }^{235}$

Cox specifically denied that the Eucharist was a re-enactment of Christ's sacrifice, as the Catholics asserted. Further, he described the Eucharist as a service in remembrance of Christ's death and passion. At this point he seems to have already adopted memorialism as his theory of the Eucharist. He also joined other reformers in proposing that the Mass should only be celebrated in the presence of a congregation, and not by the priest alone.

Throughout Cox's career as a priest and bishop, he seems to have been guided by the theology expressed in his responses to these questions. His

\section{DNB.}

235. Burnet, Reformation, Vol. 4, 273-78. 
theology seems to have been quite similar to that of Cranmer. ${ }^{236}$

There has been some speculation as to why Cox was never selected to be archbishop of Canterbury. According to Strype this was because of Cox's opposition to Elizabeth on the subject of marriage, both her reluctance to marry and the issue of clerical marriage..$^{237}$ However, Cox still had a great deal of influence over ecclesiastical matters during the first half of Elizabeth's reign. He made a significant contribution to the Elizabethan Settlement-both its definition and its enforcement. The Settlement as implemented in the diocese of Ely probably was closer to its original form than in any other diocese. However, it was therefore narrower and less flexible, and, thereby, perhaps less durable.

236. However, they did not share precisely the same theory of the Eucharist. For Cranmer's views on the Real Presence see Cranmer, "Defence," in Work, 208-209.

237. John Strype, The Life and Acts of John Whitgift, Vol. 1 (Oxford: Clarendon Press, 1822), 2. 


\section{CHAPTER VII}

\section{CONCLUSIONS}

Patrick Collinson sub-titled his biography of Archbishop Grindal, "The Struggle for a Reformed Church." I have focused on three bishops from the first half of Elizabeth's reign as a means of illustrating that concept. The implementation of the Settlement of Religion was a struggle, and the bishops played a major role. Through their participation in the Convocations and especially through their individual episcopal administration, they helped define and implement the Settlement. Richard Cox probably did more. He was probably involved in the initial design of the Settlement, especially the Act of Uniformity and the new Prayer Book. All the early Elizabethan bishops were agents of change.

Christopher Haigh describes the earlier phases of the English Reformation as a "piecemeal Reformation," saying,

[The English people] could not recognize a composite Reformationevent, they could see only the little events which might, in sum, add up to a Reformation. The political activists of Tudor England did not elect for or against 'the Reformation' in a single do-or-die decision, they made a number of lesser choices ... . and England 
accepted its Reformation because it didn't quite see what it was doing. 238

But by the beginning of Elizabeth's reign the situation had changed. Mary had spent five years attempting to restore Catholicism. Elizabeth, her successor, was illegitimate in the eyes of the papacy. Most of the Elizabethan bishops and many of the priests had either hidden in England or fled to exile on the Continent during the Catholic restoration. At the beginning of Elizabeth's reign, all the religious leaders, as well as many of the political leaders, knew very well that they were involved in creating or approving what Christopher Haigh referred to as a composite Reformation event. ${ }^{239}$ A Protestant Church of England was the goal.

In particular, Elizabeth seems to have had a clear vision of the form of Protestantism she wanted to restore to England, although there has been much debate concerning her personal theology. As Jones said, for her the key was her authority as embodied in the royal supremacy. All else would follow. ${ }^{240}$ The secondary priorities were liturgy and theology, but primarily liturgy. It is not surprising in this context that theology did not receive more attention.

238. Christopher Haigh, "Introduction," in The English Reformation Revised (New York: Cambridge University Press, 1987), 16-17.

239. In particular, William Cecil seems to have played a key role in both the design of the Settlement and the selection of the Elizabethan bishops.

240. Jones, Faith by Statute, 9 . 
The English Reformation was accomplished without a clear statement of the theology of the English Church. ${ }^{241}$ In fact, the liturgy contained in the Prayer Books served as the primary vehicle for the articulation of theology. Therefore, the Elizabethan Settlement, which sought to restore Protestantism to England, did so mainly through the liturgy, and most of the debates about the nature of the Settlement were debates over aspects of the liturgy.

Parliament approved a new Book of Common Prayer as a part of the Act of Uniformity of 1559 , but it did not determine the precise content of that book. A small group of clergy probably accomplished that, working in consultation with Cecil and subject to the queen's approval. The new book was almost identical to the second Prayer Book of Edward VI, but we do not know exactly who made the revisions. Several of the clergy who were in London during the early part of 1559 had been in exile during Mary's reign, ${ }^{242}$ and while in exile they had performed a similar function. They had designed liturgies acceptable to the various magistracies in authority where they lived and worshipped. Those who were now being given opportunities for leadership had based their continental

241. Even the Articles of Religion do not completely define the theology of the Church of England. As Dugmore has pointed out, they are more a set of statements which refute the theology of other religions. Dugmore, "The Thirtynine Articles," 165. 
liturgies on the 1552 Prayer Book. ${ }^{243}$

Chief among the exiled liturgists, of course, was Richard Cox. His intimate knowledge of the drafting of the first two Prayer Books, plus his participation in the proceedings at Frankfurt, would have made his contributions to the creation of the Book of Common Prayer of 1559 particularly valuable, although there is no clear evidence that he was actually consulted. Further, he had been involved in both the Henrician and the Edwardian phases of the English Reformation at the highest level. His experience and involvement in those earlier phases of the Reformation set him apart from all the other Elizabethan bishops. ${ }^{244}$

Parkhurst and Cheyney formed the "theological book-ends" for the early Elizabethan episcopacy. Parkhurst was arguably the most Protestant-the most radical. Cheyney was the most conservative-the closest to Catholicism. As a fellow exile with Cox, John Parkhurst had had some experience with modified English liturgies, and he also had favored using the second Prayer Book as the basis for those modifications. Richard Cheyney could claim no such experience, having stayed in England and kept his preferments through Mary's reign. He had not been exposed to continental liturgies.

243. Knox was not allowed to return to England, and the others who sided with him on the continent do not seem to have been given any opportunity to help lead England back to Protestantism. Jones, Faith by Statute, 12-13.

244. A few others had some involvement, but none equalled that of Cox. 
These three men also represented the full spectrum of administrative abilities found in the early Elizabethan bishops. Cox may not have been the only skilled administrator, but he was one of a very few. In this instance Parkhurst and Cheyney more nearly represent the norm. Most of Elizabeth's first group of bishops were much better preachers than administrators. ${ }^{245}$

By examining the theology and administrations of these three men, we can gain some sense of the nature of the episcopacy from approximately 1559 to 1575-80. These same men provide some insights into the final design and implementation of the Settlement of Religion. Even the most theologically extreme bishops during the first half of Elizabeth's reign were fairly moderate. Parkhurst may have preferred a simpler liturgy, but he viewed vestments as things that were indifferent. Cheyney may have believed in the Real Presence, but he accepted the royal supremacy and the Prayer Book. The bishops with the most stature and influence were men like Cox. They were theologically more moderate or at least more Erastian. In the Convocation of 1563 they wanted to further define English Protestantism, and most of them had experienced other forms of Protestantism during Mary's reign. However, they were willing to accede to the queen's authority and define a moderate form of Protestantism, even one that included some ambiguities. Thus they were able to create a church which was theologically broad enough to allow for some private

245. Houlbrooke, "Protestant Episcopate," 82-83; Collinson, "Episcopacy and Reform," 171-72. 
differences within the definition of outward conformity, provided by the liturgy. It was theologically broad enough to withstand the tests of successive generations of reformers and restorers, and to survive to the present in a form remarkably similar to that which was adopted by the Convocation of 1563 . 


\section{ABBREVIATIONS}

$\underline{\text { APC }}$

Ath. Cant.

$\underline{B L}$

Cal. of Patent Rolls

Cal. S. P.. Dom.

$\underline{\text { DNB }}$

Prayer Books
Acts of the Privy Council

Athenae Cantabrigienses

British Library

Calendar of Patent Rolls

Calendar of State Papers, Domestic

The Dictionary of National Biography

The First and Second Prayer Books of Edward VI 


\section{REFERENCES}

A brieff discours off the troubles begonne at Franckford in Germany Anno Domino 1554, abowte the booke off common prayer and ceremonies. Zurich(?): C. Froschauer, 1574(?). STC 25442.

A Collection of Original Letters from the Bishops to the Privy Council, 1564 Ed. Mary Bateson. 1895. Reprint. New York: Johnson Reprint Corp., 1965.

Acts of the Privy Council of England. New Series. Vol. 3. A.D. 1550-1552.

Ed. John R. Dasent. London: Eyre and Spottiswoode, 1891.

Atkinson, D. W. "Devotional Responses to Doctrinal Dilemmas: Piety in the English Reformation." Historical Magazine of the Protestant Episcopal Church 52 (1983): 167-79.

Berlatsky, J. A. "Thomas Bentham and the Plight of the Early Elizabethan Bishops." Historical Magazine of the Protestant Episcopal Church 43 (1974): 317-40.

Blunt, John Henry. The Annotated Book of Common Prayer, forming a Concise Commentary on the Devotional System of the Church of England. London: Rivington's, 1872.

The Book of Common Prayer, 1559: the Elizabethan Prayer Book. Ed. John E. Booty. Charlottesville: University of Virginia Press for the Folger Shakespeare Library, 1976.

Booty, John E. John Jewel as Apologist of the Church of England. London: SPCK, 1963.

Bridges, George F. The Oxford Reformers and English Church Principles. Ed. W. G. Bridges. London: Elliot Stock, 1908.

Brightman, F. E. The English Rite; A Synopsis of the Sources and Revisions of the Book of Common Prayer. 2 vols. London: Rivington's, 1915. 
Brook, Victor John Knight. The Life of Archbishop Parker. Oxford:

Clarendon Press, 1962.

Bucer, Martin. Martin Bucer and the Book of Common Prayer. Ed. E. C. Whitaker. Great Wakering: Mayhew-McGrimmon, 1974.

Buchanan, Colin O. What did Cranmer think he was doing?. Bramcote: Grove Books, 1976.

Burnet, Gilbert. The History of the Reformation of the Church of England.

New ed. 4 vols. London: Reeves and Turner, 1880.

Calendar of the Patent Rolls, Elizabeth. Vols. 1-2. London: His Majesty's Stationery Office, 1939.

Calendar of State Papers Domestic Series, of the Reigns of Edward VI, Mary, Elizabeth, 1547-1580. 142 vols. Ed. Robert Lemon. London: Longman, Brown, Green, Longman's, and Roberts, 1856.

Calendar of State Papers Foreign Series, of the Reign of Elizabeth, 1558-1559.

Ed. Joseph Stevenson. London: Longman, Brown, Green, Longman's, and Roberts, 1863.

Calendar of State Papers and Manuscripts, relating to English Affairs, existing in the Archives and Collections of Venice. Vol. 7. 1558-1570. Ed. Rawdon Brown and G. Cavendish Bentwinck. London: Eyre and Spottiswoode, 1890.

Calvin, John. John Calvin, Selections from his Writings. Ed. John Dillenberger. Missoula, Montana: Scholars Press, 1975.

Cardwell, Edward. History of Conferences and Other Proceedings Connected with the Revision of the Book of Commmon Prayer. Oxford: Oxford University Press, 1849.

Cate, Fred H. "Thomas Cranmer's Eucharistic Doctrine and the Prayer Books of Edward VI." Historical Magazine of the Protestant Episcopal Church 55 (June, 1986): 95-111.

Certain Sermons or Homilies appointed to be read in Churches in the Time of the Late Queen Elizabeth. Ed. Anon. Oxford: Oxford University Press, 1840. 
Chadwick, Owen. The Reformation. Grand Rapids, Michigan: William B. Erdmans, 1964.

Chapman, Hester W. The Last Tudor King: A Study of Edward VI. New York: Macmillan Co., 1958.

Cheyney, Richard. "Letter to Sir William Cecil, from Lekyngton, 17 September 1563." British Library Lansdowne Collection 6, 72 (fol. 174).

Christianson, P. "Reformers and the Church of England under Elizabeth and the Early Stuarts." Journal of Ecclesiastical History 31 (1980): 483-82.

Clay, William K. Liturgical Services, Liturgies and Occasional Forms of Prayer set forth in the Reign of Queen Elizabeth. Cambridge: The Parker Society, 1847.

Collinson, Patrick. "A Chosen People? The English Church and the Reformation." History Today 36 (March, 1986): 14-20.

- Archbishop Grindol 1519-1583: The Struggle for a Reformed

Church. Berkeley, California: University of California Press, 1979.

- "The Authorship of 'A brieff discours off the troubles begonne at Franckford'." Journal of Ecclesiastical History 9 (October, 1958): 188-208.

- Godly People: Essays on English Protestantism and Puritanism.

London: Hambledon Press, 1983.

- The Religion of the Protestants: The Church in English Society, 1559-1625. Oxford: Clarendon Press, 1983.

Constant, Gustave L. M. J. The Reformation in England: The English Schism and Henry VIII, 1509-1547. Trans. R. E. Scantlebury. New York: Harper and Row, 1934.

Cooper, C. H. Annals of Cambridge. 5 vols. Cambridge: Cambridge University Press, 1842-1908.

Athenae Cantabrigienes. Vol 1. Cambridge: Deighton and Bell, 
Cox, Richard. "Letter Book of Bishop Cox of Ely." Gonville and Caius College MS 53/30, 1-18 (fols. 1-166).

. "Letter to Sir William Cecil, from Cambridge, August, 1563." British Library Lansdowne Collection 6, 67 (fol. 164).

Cranmer, Thomas. The Work of Thomas Cranmer. Ed. G. E. Duffield. Philadelphia: Fortress Press, 1965.

- Writings and Disputations of Thomas Cranmer, relative to the Sacrament of the Lord's Supper. Ed. John E. Cox. Cambridge: Cambridge University Press, 1844.

Creighton, Mandell. Queen Elizabeth. 1899. Reprint. New York: Thomas Y. Crowell, 1966.

Cross, Claire. Church and People, 1450-1660: The Triumph of the Laity in the English Church. Hassocks, Sussex: Harvester Press, 1976.

- The Royal Supremacy in the Elizabethan Church. New York: Barnes and Noble, 1969.

Cuming, Geoffrey J. A History of Anglican Liturgy. 2nd ed. London: Macmillan, 1982.

Davies, Horton. Worship and Theology in England from Cranmer to Hooker, 1534-1603. Princeton: Princeton University Press, 1970.

Davis, E. Jeffries. "Archbishop Parker's Register." English Historical Review 34 (1919): 257-60.

Dent, Christopher M. Protestant Reformers in Elizabethan Oxford. Oxford: Oxford University Press, 1983.

D'Ewes, Simonds A. A Complete Journal of the Votes, Speeches and Debates both in the House of Lords and House of Commons throughout the Whole Reign of Queen Elizabeth. 1682. Reprint. Shannon: Irish University Press, 1973.

Dickens, A. G. "The Early Expansion of Protestantism in England, 1520-1558." Archive for Reformation History 78 (January, 1987): 187-221.

- The English Reformation. New York: Schocken Books, 1964. 
- Lollards and Protestants in the Diocese of York, 1509-1558. 1959.

Reprint. London: The Hambledon Press, 1982.

The Dictionary of National Biography. 22 vols. Ed. Leslie Stephen and Sidney Lee. 1917. Reprint. London: Oxford University Press, 1950.

Dixon, Richard W. History of the Church of England from the Abolition of the Roman Jurisdiction. 6 vols. Oxford: Oxford University Press, 1872-1902.

Documentary Annals of the Reformed Church of England ... from the Year 1546 to the Year 1716. 2 vols. Ed. Edward Cardwell. Oxford: Oxford University Press, 1844.

Documents illustrative of English Church History. Ed. Henry Gee and William J. Hardy. New York: Macmillan and Co., 1896.

Dowling, Maria. Humanism in the Age of Henry VIII. Dover, New Hampshire: Croom Helm, 1986.

Dugmore, Clifford William. The Mass and the English Reformers. New York: St. Martin's Press, 1958.

. "Foundation Documents of the Faith; VI. The Thirty-nine Articles." Expository Times 91 (March, 1980): 164-67.

Elton, Geoffrey R. England under the Tudors. 1955. Reprint. New York: Methuen, 1974.

- Reform and Reformation: England, 1509-1558. Cambridge, Massachussetts: Harvard University Press, 1977.

- Reform and Renewal: Thomas Cromwell and the Common Weal. New York: Cambridge University Press, 1973.

English Historical Documents, Vol. 5, 1485-1558. Ed. C. H. Williams. New York: Oxford University Press, 1967.

The English Reformation Revised. Ed. Christopher Haigh. New York: Cambridge University Press, 1987.

Erasmus. "On the Freedom of the Will." Luther and Erasmus: Free Will and Salvation. Trans. and Ed. E. Gordon Rupp, 35-97. Philadelphia: Westminster Press, 1969. 
The First and Second Prayer Books of Edward VI. (Everyman's Library) 1910. Reprint. New York: E. P. Dutton and Co., 1960.

Foxe, John. The Acts and Monuments of John Foxe. 8 vols. Ed. Stephen R. Cattley. London: R. B. Seeley and W. Burnside, 1838.

Frere, Walter H. The English Church in the Reigns of Elizabeth and James I. (1558-1625). London: Macmillan and Co., 1904.

Fuller, Thomas. History of the Worthies of England. 2 vols. Ed. John Nichols. London: 1811.

Gardiner, Stephen. The Letters of Stephen Gardiner. Ed. James A. Muller. 1933. Reprint. Westport, Connecticut: Greenwood Press, 1970.

Garrett, Christina H. The Marian Exiles: a Study in the Origins of Elizabethan Puritanism. 1938. Reprint. Cambridge: Cambridge University Press, 1966.

Gasquet, Francis A. and Edmund Bishop. Edward VI and the Book of

Common Prayer. 3rd ed. London: Sheed and Ward, 1928.

Gee, Henry. The Elizabethan Clergy, and the Settlement of Religion, 1558-1564. Oxford: Clarendon Press, 1898.

- The Elizabethan Prayer Book and Ornaments, with an Appendix of Documents. New York: Macmillan Co., 1902.

Hall, Basil. "The Early Rise and Gradual Decline of Lutheranism in England (1520-1600)." Reform and Reformation: England and the Continent c.1500 - c.1750. Ed. Derek Baker, 103-31. Oxford: Basil Blackwell, 1979.

Grindal, Edmund. Grindal's Remains. Ed. W. Nicholson. Cambridge: Parker Society, 1843.

Haigh, Christopher. "The Continuity of Catholicism in the English Reformation." The English Reformation Revised. Ed. Christopher Haigh, 176-208.

New York: Cambridge University Press, 1987.

Hardwick, Charles. A History of the Articles of Religion to which is added a Series of Documents from A.D. 1536 to A.D. 1615. London: George Bell and Sons, 1904. 
Haugaard, William P. Elizabeth and the English Reformation: The Struggle for a Stable Religious Settlement. Cambridge: Cambridge University Press, 1968.

Hayward, John. Annals of the First Four Years of the Reign of Elizabeth. Ed. John Bruce. London: Nichols and Son, 1840.

Heal, Felicity. Of Prelates and Princes: a Study of the Economic and Social Position of the Tudor Episcopate. Cambridge: Cambridge University Press, 1980.

Hoak, D. E. The King's Council in the Reign of Edward VI. Cambridge: Cambridge University Press, 1976.

Houlbrooke, Ralph. "The Protestant Episcopate, 1547-1603: The Pastoral Contribution." Church and Society in England, Henry VIII to James I. Ed. Felicity Heal and Rosemary O'Day, 78-98. London: Macmillan, 1977.

Hudson, Winthrop S. The Cambridge Connection and the Elizabethan Settlement. Durham, North Carolina: Duke University Press, 1980.

Index of Manuscripts in the British Library. 10 vols. Cambridge: ChadwyckHealey, 1984.

Jewel, John. An Apology or Answer in Defence of the Church of England. Ed. John E. Booty. 1564. Reprint. Ithaca, New York: Cornell University Press, 1963.

- The Works of John Jewel. 4 vols. Ed. John Ayre. Cambridge: Cambridge University Press, 1840-50.

Jones, Norman L. Faith by Statute: Parliament and the Settlement of Religion, 1559. New Jersey: Humanities Press for the Royal Historical Society, 1982.

Jordan, W. K. Edward VI: The Threshold of Power. London: George Allen and Unwin, 1968.

- Edward VI: The Young King. London: George Allen and Unwin, 1968. 
Keep, David J. "Theology as a Basis for Policy in the Elizabethan Church." The Materials, Sources and Methods of Ecclesiastical History. Ed. Derek Baker, 263-68. Oxford: Basil Blackwell, 1975.

Keltey, Joseph. The Two Liturgies, A.D. 1549 and A.D. 1552: with Other Documents set forth by Authority in the Reign of King Edward VI. Cambridge: Cambridge University Press, 1844.

Knox, John. "A Narrative of the Proceedings and Troubles of the English Congregation at Frankfurt on the Main, 1554-5." The Works of John Knox. Vol. 4. Ed. David Laing, 41-49. Edinburgh: James Thin, 1905. 41-49.

Lander, Stephen. "Church Courts and the Reformation in the Diocese of Chichester." The English Reformation Revised. Ed. Christopher Haigh, 34-55. Cambridge: Cambridge University Press, 1987.

Letters and Papers, Foreign and Domestic, of the Reign of Henry VIII. 21 vols. Arr. and Cat. James Gairdner and R. H. Brodie. 1880. Reprint. London: Kraus Reprint Ltd., 1905.

Levy, F. J. Tudor Historical Thought. San Marino, California: Huntington Library, 1967.

The Liturgy of Compromise used in the English Congregation at Frankfort. Ed. George W. Sprott. London: William Blackwood and Sons, 1905.

Luther, Martin. "The Freedom of a Christian." Martin Luther: Selections from his Writings. Ed. John Dillenberger, 42-85. Garden City, New Jersey: Doubleday and Co., 1961.

. "On the Bondage of the Will." Luther and Erasmus: Free Will and Salvation. Trans and Ed. Philip S. Watson, 101-334. Philadelphia: Westminster Press, 1969.

MacCulloch, Diarmaid. Suffolk and the Tudors: Politics and Religion in an English County, 1500 - 1600. Oxford: Clarendon Press, 1986.

Machyn, Henry. The Diary of Henry Machyn, from A.D. 1550 to A.D. 1563. Ed. John G. Nichols. London: J. B. Nichols and Sons, 1848.

Maclure, Millar. The Paul's Cross Sermons, 1534-1642. Toronto: University of Toronto Press, 1958. 
Maitland, F. W. "Elizabethan Gleanings: Supremacy and Uniformity." English Historical Review 18 (1903): 517-32.

Manning, Roger B. "The Crisis of Episcopal Authority During the Reign of Elizabeth I." Journal of British Studies 11 (November, 1971): 1-25.

McConica, James K. English Humanists and Reformation Politics Under Henry VIII and Edward VI. London: Oxford University Press, 1965.

Mozley, J. F. John Foxe and His Book. New York: Macmillan Co., 1940.

Narratives of the Days of the Reformation. Ed. John G. Nichols. London: Camden Society, 1859.

Neale, John E. Elizabeth I and her Parliaments. 2 vols. 1958. Reprint. New York: W. W. Norton and Co., 1966.

. "The Elizabethan Acts of Supremacy and Uniformity." English Historical Review 65 (June, 1950): 304-32.

- Queen Elizabeth I: A Biography. 1934. Reprint. Garden City, New York: Doubleday and Co., 1957.

O'Day, Rosemary. The Debate on the English Reformation. New York: Methuen, 1986.

Original Letters Illustrative of English History. 11 vols, 3 series. Ed. Henry Ellis. 1824-46. Reprint. London: Dawsons of Pall Mall, 1969.

Original Letters relative to the English Reformation, written during the Reigns of King Henry VIII, Edward VI, and Queen Mary: Chiefly from the Archives of Zurich. 2 vols. Trans. and Ed. Hastings Robinson. Cambridge: Cambridge University Press, 1846.

Overall, M. A. "Peter Martyr in England, 1547-1553: An Alternative View." Sixteenth Century Journal 15 (Spring, 1984): 86-104.

Parker, Matthew. The Correspondence of Matthew Parker. Ed. John Bruce and Thomas Thomason. Cambridge: Cambridge University Press, 1853.

Parker, T. M. The English Reformation to 1558. 1966. Reprint. New York: Oxford University Press, 1976. 
Parkhurst, John. The Letter Book of John Parkhurst. Ed. Ralph Houlbrooke. Norwich: Norfolk Record Society, 1974/5.

. "On the Jurisdiction and Management of his Diocese." British Library Lansdowne Collection 6, 60 (fol. 141).

- "Report on Diocesan Organizational Structure." British Library Lansdowne Collection 6, 60 (fols. 148-50).

Philpot, John. The Examination and Writings of John Philpot, Archdeacon of Winchester, Martyr, 1555. Ed. Robert Eden. Cambridge: Cambridge University Press, 1842.

Pogson, Rex H. "The Legacy of the Schism: Confusion, Continuity and Change in the Marian Clergy." The Mid-Tudor Polity c.1540 - 1560. Ed. Robert Titler and Jennifer Loach, 116-36. Totowa, New Jersey: Rowman and Littlefield, 1980.

- "Reginald Pole and the Priorities of Government in Mary Tudor's Church." The Historical Journal 18 (1975): 3-20.

Pollard, A. W. and G. R. Redgrave, ed. A Short Title Catalogue of Books printed in England from 1485 to 1641. 2nd ed. Ed. W. A. Jackson, F. S. Ferguson, Katharine F. Pantzer. London: The Biographical Society, 1976.

Pollard, Albert F. Thomas Cranmer and the English Reformation. New York: G. P. Putnam's Sons, 1904.

Powicke, Maurice. The Reformation in England. 1941. Reprint. New York: Oxford University Press, 1967.

Price, F. Douglas. "The Abuses of Excommunication and the Decline of Ecclesiastical Discipline under Queen Elizabeth." The English Historical Review 57 (January, 1942): 106-15.

Proctor, Francis and Walter H. Frere. A New History of the Books of Common Prayer with a Rationale of its Offices. London: Macmillan and Co., 1914.

Pruett, Gordon E. "Thomas Cranmer's Progress in the Doctrine of the Eucharist, 1535-1548." Historical Magazine of the Protestant Episcopal Church 45 (December, 1976): 439-58. 
Pulman, Michael B. The Elizabethan Privy Council in the Fifteen Seventies.

Berkeley, California: University of California Press, 1971.

Ratcliff, Edward C. The Book of Common Prayer of the Church England: Its Making and Revisions. London: Sun Printers, 1949.

. "The Liturgical Works of Archbishop Cranmer." Journal of Ecclesiastical History 7 (October, 1956): 189-203.

The Reformation Crisis. Ed. Joel Hurstfield. New York: Harper and Row, 1965.

Reformation Europe: a Guide to Research. Ed. Stephen Ozment. St. Louis: Center for Reformation Research, 1982.

The Reformation in England to the Accession of Elizabeth I. Ed. A. G. Dickens and Dorothy Carr. 1967. Reprint. London: Edward Arnold Ltd., 1971.

Register of the University of Oxford. Vol. 1. Ed. C. W. Boase. Oxford: Clarendon Press, 1885.

Ridley, Jasper. John Knox. Oxford: Clarendon Press, 1968.

- Nicholas Ridley: A Biography. London: Longman's, Green and Co., 1957.

- Thomas Cranmer. Oxford: Clarendon Press, 1962.

Rupp, E. G. Studies in the Making of the English Protestant Tradition (Mainly in the Reign of Henry VIII). Cambridge: Cambridge University Press, 1966.

Scarisbrick, J. J. Henry VIII. Berkeley, California: University of California Press, 1968.

- The Reformation and the English People. Oxford: Blackwell, 1984.

Seaver, Paul. "The English Reformation." Reformation Europe: A Guide to Research. Ed. Stephen Ozment, 271-87. St. Louis: Center for Reformation Research, 1982. 
Selected Statutes and Other Constitutional Documents illustrative of the Reigns of Elizabeth and James I. 2nd ed. Ed. G. W. Prothero. Oxford: Clarendon Press, 1898.

Simon, Joan. Education and Society in Tudor England. 1966. Reprint. Oxford: Alden Press, 1979.

Smith, Lacey Baldwin. Elizabeth Tudor: Portrait of a Queen. 1922. Reprint. Boston: Little, Brown and Co., 1975.

Smyth, C. H. Cranmer and the Reformation under Edward VI. Cambridge: Cambridge University Press, 1926.

Spufford, Margaret. "The Quest for the Heretical Laity in the Visitation Records of Ely in the Late Sixteenth and Early Seventeenth Centuries." Schism, Heresy and Religious Protest. Ed. Derek Baker, 223-30. Cambridge: Cambridge University Press, 1972.

State Papers of King Henry the Eighth, Parts 1 and 2. London: His Majesty's Commission, 1830.

Strype, John. Annals of the Reformation and Establishment of Religion, and Other Various Occurrences in the Church of England, during Queen Elizabeth's Happy Reign. 4 vols. Oxford: Clarendon Press, 1820-40.

- The Life of the Learned Sir John Cheke. Oxford: Clarendon Press, 1821.

- Ecclesiastical Memorials Relating Chiefly to Religion and the Reformation of It. 3 vols. Oxford: Clarendon Press, 1820-40.

- The History of the Life and Acts of the Most Reverend Father in God, Edmund Grindal. 2 vols. Oxford: Clarendon Press, 1821.

. The Life and Acts of Matthew Parker. 3 vols. Oxford: Clarendon Press, 1821.

- The Life of the Learned Sir Thomas Smith. Oxford: Clarendon Press, 1820.

. The Life and Acts of John Whitgift. 4 vols. Oxford: Clarendon Press, 1822. 
- Memorials of the Most Reverend Father in God Thomas Cranmer.

3 vols. Oxford: Oxford University Press, 1840.

Synodalia. A Collection of Articles of Religion, Canons, and Proceedings of Convocations in the Province of Canterbury from the Year 1547 to the Year 1717. 2 vols. Ed. Edward Cardwell. 1842. Reprint. Farnborough, Hants.: Gregg International Publishers, 1968.

Thompson, Craig Ringwalt. The English Church in the Sixteenth Century.

Washington, D.C.: Folger Shakespeare Library, 1958.

Thompson, W. D. J. Cargill. "John Strype as a Source for the Study of Sixteenth Century English Church History." The Materials, Sources and Methods of Ecclesiastical History. Ed. Derek Baker, 237-47. Oxford: Basil Blackwell, 1975.

Titler, Robert. The Reign of Mary I. New York: Longman, 1983.

Tudor Royal Proclamations. 3 vols. Ed. Paul L. Hughes and James F. Larkin. New Haven: Yale University Press, 1964-9.

Verkamp, Bernard J. The Indifferent Mean: Adiaphorism in the English Reformaiton to 1554. Athens, Ohio: Ohio University Press, 1977.

Weikel, Ann. "The Marian Council Revisited." The Mid-Tudor Polity. Ed. Robert Titler and Jennifer Loach, 52-73. Totowa, New Jersey: Rowman and Littlefield, 1980.

White, F. O. Lives of the Elizabethan Bishops of the Anglican Church. London: Skeffington and Son, 1898.

Wood, Anthony A. Athenae Oxonienses. An Exact History of All the Writers and Bishops who have had Their Education in the University of Oxford. 4 vols. London: F. C. and J. Rivington, 1813.

Woodhouse, H. F. The Doctrine of the Church in Anglican Theology, 15471603. New York: The MacMillan Co., 1954.

Wriothesley, Charles. A Chronicle of England During the Reigns of the Tudors, from A.D. 1485 to 1559.2 vols. Ed. William D. Hamilton. London: Camden Society, 1877. 
The Zurich Letters, comprising the Correspondence of Several English Bishops and Others with Some of the Helvetian Reformers 3 vols. Trans. and Ed. Hastings Robinson. Cambridge: Cambridge University Press, 1842, 1845 . 


\section{APPENDIX A}

BISHOPS OF THE CHURCH OF ENGLAND IN 1563

Name

William Alley

William Barlow

Thomas Bentham

Gilbert Berkeley

John Best

Nicholas Bullingham

Richard Cheyney

Richard Cox

Richard Davies

Thomas Davies

William Downham

Robert Horn

Edmund Grindal

Edmund Guest

John Jewel

Anthony Kitchen
Diocese

Exeter

Chichester

Coventry \& Litchfield

Bath \& Wells

Carlisle

Lincoln

Gloucester \& Bristol

Ely

St. David's

St. Asaph's

Chester

Winchester

London

Rochester

Salisbury

Llandaff
Date of Nomination

March 1560

June/July 1559

December 1559

December 1559

December 1560

November 1559

February 1562

June/July 1559

May 1561

May 1561

December 1560

Fall 1560

June/July 1559

December 1559

June/July 1559

1553 
BISHOPS OF THE CHURCH OF ENGLAND IN 1563 (Continued)

Name

Diocese

Date of Nomination

Rowland Merrick

Bangor

November 1559

Matthew Parker

Canterbury

June/July 1559

John Parkhurst

Norwich

March 1560

James Pilkington

Durham

December 1560

Edwin Sandys

Worcester

November 1559

Edmund Scambler

Peterborough

December 1560

John Scory

Hereford

June/July 1559

Thomas Young

York

Fall 1560 


\section{APPENDIX B}

\section{ACTIVITIES OF \\ ELIZABETHAN BISHOPS DURING MARY'S REIGN}

Name

William Alley

William Barlow

Thomas Benthem

Gilbert Berkeley

John Best

Nicholas Bullingham

Richard Cheyney

Richard Cox

Richard Davies

Thomas Davies

William Downham

Robert Horn
Diocese

Exeter

Chichester

Coventry \& Litchfield

Bath \& Wells

Carlisle

Lincoln

Gloucester \& Bristol

Ely

St. David's

St. Asaph's

Chester

Winchester
Chaplain to

Elizabeth

During Mary's Reign

Hiding in England

Exile

Minister to London

Protestants

Exile

Unknown

Exile

Archdeacon of

Hereford

Exile

Exile

Priest in England

Exile 
Name

Edmund Grindal

Edmund Guest

John Jewel

Anthony Kitchen

Rowland Merrick

Matthew Parker

John Parkhurst

James Pilkington

Edwin Sandys

Edmund Scambler

John Scory

Thomas Young
Diocese

London

Rochester

Salisbury

Llandaff

Bangor

Canterbury

Norwich

Durham

Worcester

Peterborough

Hereford

York
During Mary's Reign

Exile

Hiding in England

Exile

Bishop in England

Unknown

Hiding in England

Exile

Exile

Exile

Minister to London

Protestants

Exile

Exile 